Endocrinol. Jap., Vol. 1, No. 1 (1954).

\title{
BIOGHEMICAL STUDIES ON SALIVARY GLAND HORMONE
}

\author{
YOSOJI ITO \\ Institute of Physiological Chemistry, Department of Pharmacy, Faculty of Medicine, \\ Tokyo University and Endocrinological Laboratories, School \\ of Medicine, Gunma University \\ THIRTY-SIX FIGURES
}

In order to prove the validity of the 'salivary gland endocrine theory' proposed by Dr. T. Ogata (Tokyo University)1a), the author and his collaborators have engaged in this study for approximately 15 years. In 1944, the author and his associates succeeded in isolating a crude protein from the bovine parotid gland which remarkably promoted the calcification of teeth and reduced the calcium level in serum. This protein was named 'parotin' by Drs. T. Ogata, A. Ogata, and the author $1 \mathrm{~b})$. Later in 1949, this crude parotin was purified to be electrophoretically homogeneous2). Since 1951, studies have been made by the consolidated research group, organized on the Grant in aid for Scientific Research from the Ministry of Education from various angles to determine if this protein is the salivary gland hormone itself ${ }^{3)}$. So far, it has been proved morphologically and biochemically by many scholars that this parotin possesses specific action of promoting the growth of hard tissues, such as teeth and bones. This action is, according to the salivary gland endocrine theory, the main action of the hormone. It has also been found that parotin, when it is given to normal animals, causes experimental hypersialadenism (symptoms due to hyperfunction of the salivary glands). When it is given to animals which show asialadenism (symptoms due to salivary glands ectomization), it compensates the defficiency symptoms in both hard tissue and in many functions of the parotid gland hormone which have been discovered recently.

This paper is a general review of the study of parotin made by the research group and centers upon biochemical research of this hormone performed in the laboratories of the author. Any suggestion and criticism of the study would be very much appreciated by the author.

\section{BIOASSAY OF PAROTIN}

The crude parotin was extracted by the author and was histologically assayed by Dr. Z. Ishii (Shinshu University).

This parotin was found to have a strong calcification effect on rat teeth and the hard tissues around them by histological study4).

In the mean time the author and his associates discovered5) that parotin lowered calcium level in rabbit serum and the mode of such lowering was quite

Received for publication April 30, 1954, 
different from that of bovine serum albumin and globulin, and the isoelectric point precipitating fraction extracted from the liver, spleen, heart muscle and thymus gland by the same methods that of parotin. Furthermore, the activity estimated by the serum calcium reduction assay method was identical with that of the histological test by Ishii6). Thus, putting aside the study as to what relation calcium reduction has with the calcification effect, the amount of calcium reduction was used as a standard of the activity of parotin, because the histological test of tooth is inconvenient for the chemical study of parotin. The question of whether this calcium test satisfies the minimum conditions of bioassay was examined on the following points :

1. On the change of calcium level in rabbit serum caused by frequent blood drawing: The serum calcium level reaches the minimum value three to eight hours after the subcutaneous injection of a medium dose of crude parotin into rabbit. Therefore, in this bioassay the blood had to be taken several times at certain intervals during the day after parotin injection and calcium level was measured. Therefore, the limit of the number of blood drawing per day that effected the serum calcium level was examined. When less than four cc. of blood was taken three times, the arithmetic average of the maximum changes of calcium level was less than 3\%, and when blood was drawn five times $4.7 \%$ of change was observed (average of eight examples). Thus it was found experimentally that blood drawing of this frequency did not cause serious change in the serum calcium level?).

2. Effect of breeding conditions: The change of serum calcium level can be observed in one day and daily variation need not be considered. Since the degree of reaction is measured by the decrease ratio, namely the percentage of the minimum value of calcium decrease after the injection against the value of calcium just before injection, the absolute value of calcium in serum does not have to be considered. The important point is to keep the sensitivity of each animal equal. Considering these, the rabbits were kept under the same conditions and were used after fasting for 24 hours?).

3. The relation between dose and effect: Examination with various preparations of crude parotin showed that the parotin effect is approximately in proportion to the dose within the range of 7.5 to $30 \mathrm{mg} .7$ ).

4. The sensitivity of rabbits: When the same rabbit was used, the amount of serum calcium reduction did not vary from day as long as the same amount of the same preparation was used and the reduction was in proportion to the amount injected. When various effective and ineffective fractions were administered to the same rabbit, the response occurred accordingly. Furthermore, no serious changes in sensitivity of a rabbit were seen after the administration of various effective fractions to the same rabbit, twenty-four times during nine months. Thus, it has been discovered that immunity to parotin is not acquired as in the case of parathyroid hormone. In short, as far as the sensitivity to serum calcium reduction is concerned this animal is quite satisfactory for the test ${ }^{8}$.

5. Homogeneity of sensitivity of individual rabbit: The same amount of crude parotin having a medium effect was injected into several rabbits and the serum 
calcium level lowered approximately in the same rate in each animal. The difference in the maximum and minimum values of the calcium reduction rate, as long as each rabbit was healthy and normal, was less than 5\%. The error of this degree may be due to technical error in the quantitative procedures and the sensitivity of individual rabbit to serum calcium reduction by parotin may be regarded as approximately equal.

Thus, calcium reduction test was proved to be valid as an assay method for parotin but in view of the advance in modern statistics, this has much to be improved and examined, because the study of statistical analysis of scientific data had just been introduced into Japan when this method of bioassay was devised and it was impossible to take full advantage of the statistical method. The author has been seeking a chance to reexamine this method in view of the modern statistics, but because of the lack of samples and sufficient number of rabbits, unfortunately has not been able to carry it out. The following method is therefore being used tentatively8).

Male rabbits of over $2 \mathrm{~kg}$. weight are kept in individual cages and fed with fixed food for at least one to two months. Three to five rabbits, in which the maximum variation in serum calcium level from two to three blood drawings during a day does not exceed 5\%, are taken out of this group. After fasting for twenty-four hours, the sample solution is injected either subcutaneously or intravenously in proportion to their body weight. During eight hours after injection the blood is drawn three times at certain intervals and the lowest calcium value is measured. The percentage of maximum decrease against the original calcium level before injection is taken as the calcium decrease rate. The minimum amount of the sample which causes an average 15\% of calcium reduction rate in three to five rabbits is taken as one potency unit. About four cc. or less of blood but not exeeding four cc. is drawn from an auricular vein, two measurements of the calcium level in two cc. each of the same serum are made according to the Kramer-Tisdall and Clark-Collip modified method.

It is hoped that this method will be reexamined by the modern statistical method in the near future. However, in view of the fact that biological activities of this hormone other than that on hard tissues have recently been found, with attendant interest on its various clinical effects, it seemed more fitting, instead of using tissue growth or inorganic substances in serum to establish bioassay utilizing other biological activities of parotin. As the procedures involved in the test is simple and convenient, parotin action of decreasing the total amount of protein in the serum and of increasing the number of circulating leucocytes after its incipient decrease, were chosen for the bioassay method and its fundamental conditions were examined statistically ${ }^{9}$.

\section{EXAMINATION OF THE DECREASE OF TOTAL PROTEIN IN SERUM}

In order to see the effect of crude parotin on the total protein in rabbit serum, the effect of the frequency of blood drawing and the amount of blood taken on the total protein in serum was examined10). It was found that no serious change in serum protein concentration occurred when $1.5 \mathrm{cc}$. of $0.9 \%$ 
saline solution was subcutaneously injected into rabbit back after the first blood drawing, and less than $1 \mathrm{cc}$. of blood is drawn every two hours thereafter. However, when $3 \mathrm{cc}$. of blood was drawn every two hours, a significant decrease of protein in serum was observed. When the second $3 \mathrm{cc}$. of blood was taken after an interval of six hours no serious change was noticed in serum protein concentration. Therefore, $0.9 \%$ solution of crude parotin $(6 \mathrm{mg} . / \mathrm{kg} ., \mathrm{pH} 8$.$) was$ injected subcutaneously into the back after the first blood drawing. The protein concentration in serum decreased significantly $(P=0.05)$, six hours after this injection. With less than one cc. of blood drawing each time 5.5 to 8 hours after the subcutaneous injection of $7 \mathrm{mg}$. $/ \mathrm{kg}$. of crude parotin a significant decrease $(\mathrm{P}=0.05)$ from that of the control group was seen in the total protein concentration. The control group of rabbits was injected with $1.5 \mathrm{cc}$. of $0.9 \%$ saline solution. The concentration of serum protein was measured by the copper sulfate method. Since this method was likely to cause hemolysis, the result was adjusted by measuring the amount of hemoglobin by the following manner :

The hemolized serum was devided into two parts. One was used to determine the amount of hemoglobin by colorimetry after its change to reduced hemoglobin according to Bürker's method (reading of colorimeter: $H$ ). The other half of the serum was submitted to Bürker's colorimetry as it was (value: h). Since the ratio of $\mathrm{H}: \mathrm{h}$ was usually constant within a certain range (Table I), hemoglobin can easily be measured by colorimetric comparison of hemolized blood with the standard Bürker's solution.

Table I. Basic experiment on the simple determination of hemoglobin in hemolized serum

\begin{tabular}{|c|c|c|c|c|c|}
\hline Serum No. & 1 & 11 & III & IV & $V$ \\
\hline $\begin{array}{c}\text { Hemoglobin in hemolized serum } \\
\qquad H^{*} \\
h^{* *} \\
H / h\end{array}$ & $\begin{array}{l}\text { g./dl. } \\
0.329 \\
0.43 \\
0.30 \\
1.43\end{array}$ & $\begin{array}{l}0.157 \\
0.90 \\
0.62 \\
1.45\end{array}$ & $\begin{array}{l}0.144 \\
0.98_{5} \\
0.75 \\
1.42\end{array}$ & $\begin{array}{l}0.108 \\
1.30_{5} \\
0.92 \\
1.44\end{array}$ & $\begin{array}{l}0.079 \\
1.80 \\
1.25 \\
1.44\end{array}$ \\
\hline
\end{tabular}

* Readings of colorimeter in Bürker method

** Readings of colorimeter in simple method (by the authors)

Later Dr. Y. Takaoka11) (Tokyo University) found by rabbits and dogs that the amount of total protein considerably increased three months after salivary gland ectomization and the administration of purified parotin to such animals caused a conspicuous decrease in the total protein. He also confirmed the above mentioned author's observations on the protein of normal rabbits.

There is still a doubt as to whether this reaction is specific to parotin or not but since the effect is conspicuous and the experimental procedures are simple its possible application for the bioassay of parotin was examined by statistical methods.

First of all $4 \times 4$ Latin squre methods was applied on four rabbits. One cc. of $0.6 \%$ physiological saline solution containing $25 \mathrm{mg}$. of purified parotin was intravenously injected into each rabbit and one cc. of $0.6 \%$ physiological saline solution was subcutaneously injected into the control animals. Three to four cc. of blood was drawn just before the injection and four, eight, and twelve hours 
after injection. The total amount of protein in unhemolized serum was measured by a refractometer. The absolute decrease in total serum protein at respective times of blood drawing and the percentage of decrease from the initial value were submitted to variance analysis (randomized block method) to examine the significance of the difference between the control and the test.

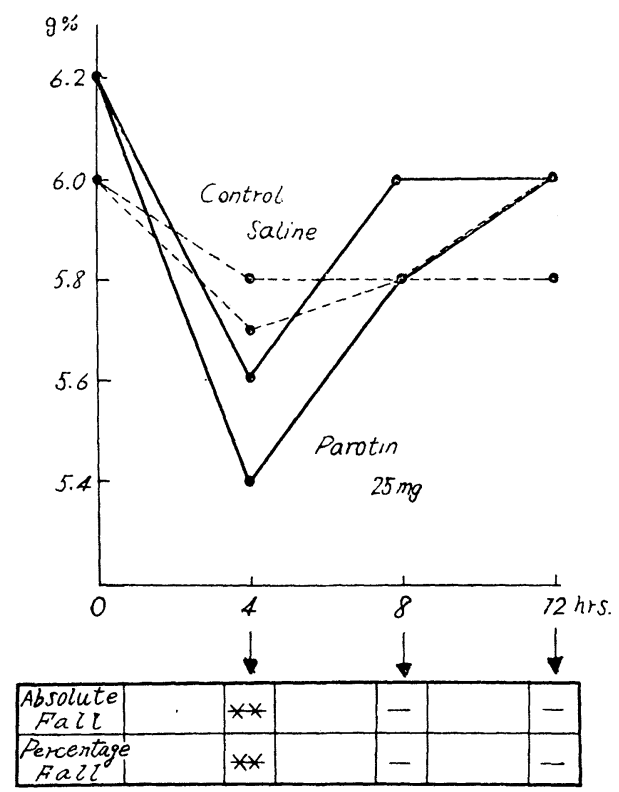

* shows to be significant at $\mathrm{P}=0.01$ and - shows to be non significant.

Fig. 1. The effect of parotin injection on the serum proten level in rabbits and the results of its significance test at various hours after injection.

As shown in Fig. 1 a significant difference $(P=0.01)$ was observed in only the difference of the absolute decrease value at four hours after injection and that of the decrease rate between treated animals and untreated animals. In other words, the total protein in the serum of the rabbit which was given $25 \mathrm{mg}$. of parotin clearly decreased as compared to that of the control, and the maximum reaction occurred within eight hours. These experiments confirmed the previous findings on the crude parotin. In addition to this, the basic relation between response and dose and the application of this to standardization were studied. As in the preceding experiment, $4 \times 4$ Latin square was also applied. The doses given were 5.4, 9.0, 15.0 and $25.0 \mathrm{mg}$. for each rabbit ( $1 \mathrm{cc}$. of $0.6 \%$ saline sol.). Total protein amount was measured before injection and at 4, 8, 12, and 24 hours after injection (Fig. 2).

To eliminate the effect of blood drawing, the rabbits were used on every fifth day but a definite decrease in body weight occurred as they were used repeatedly in the experiments and the variance of body weight by days was found to be statistically significant $(P=0.01)$. Therefore, under these conditions the value should be adjusted according to body weight by covariance for the 
estimation of dose response conditions. At the same time, the intervals between the test should be made longer and the amount of blood taken smaller, with utmost care given to the conditions of the rabbits. The variables, such as

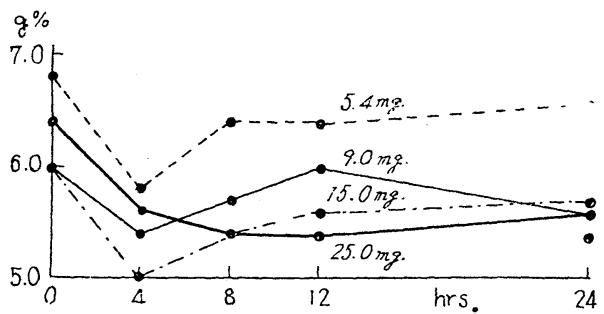

Fig. 2. The effects of various dosages of parotin on the serum protein level in rabbits.

absolute decrease in total protein and percentage of decrease, were statistically analyzed and broken down into variances caused by treatment, individuals and days. The lineality of the dose-response curve was also tested by the orthogonal polynomial method. The results showed that the lineality of the dose-response curve of mean value of the absolute decrease four hours and eight hours after injection is statistically significant $(\mathrm{P}=0.01)$ and so is the variance of the same mean value caused by different treatment (different dose). It was also found by this analysis of variance that the dose-response curve of the absolute decrease eight hours after injection was statistically linear $(P=0.01)$ and that the variance of the same absolute decrease caused by different treatment was statistically significant $(P=0.05)$. Thus, it seems possible to utilize this method for the assay of parotin. The same results were obtained by the statistical analysis of the variance and test for lineality, after adjusting the values by means of covariance according to body weight and protein content prior to injection.

\section{EXAMINATION OF THE EFFEGT ON THE NUMBER OF GIRGULATING LEUCOCYTES}

Dr. S. Tasaka (Tokyo University)12) found that the injection of parotin into the aural vein of rabbits caused selective rise in bone marrow temperature from which he concluded that parotin must have direct action on the hematopoietic function of the marrow. He carried out examination of the bone marrow picture and hemogram, and found that these pictures were changed toward a definite by parotin injection. On the other hand, Dr. Y. Takaoka (Tokyo University)11) noticed that an injection of $10 \mathrm{mg} . \mathrm{kg}$. of parotin decreased the number of circulating leucocytes very rapidly within the first from 2 to 3 hours after injection but subsequently increased the number remarkably in the next from 5 to 8 hours, and this tendency lasted even 24 hours afier injection. It was found that this first decrease occurred only in intact rats and not to adrenalectomized rats while the subsequent increase occurred even in adrenalectomized rats. Thus he concluded that this increasing reaction was not related to the adrenal body. Later, using rabbits, Dr. S. Hara (Tokyo Medical College)13) confirmed these findings. Much remains to be throughly studied as to the question of whether this action of 
parotin on the crrculating leucocytes is characteristic of parotin or not. However, judging from Dr. Tasaka's report concerning effect of parotin on bone marrow temperature, this reaction seems to be more specific to parotin than its effect on total serum protein. This leucocytes reaction was also examined statistically using the $4 \times 4$ Latin square method, in the similar manner as that for previous experiments. To examine the quantitative character of this reaction and fundamental requisites for its application to the assay of parotin, the number of leucocytes was counted on the Thoma blood counting plate with Türk's solution on fresh blood and at least three samples for each measurement were prepared for accuracy. The blood was taken just before the injection and also 1, 2, 3, 4, $5,6,8,10$, and 12 hours after injection. The rabbits once used were not used again until the fifth day to eliminate the effect of blood taking. As shown in Fig. 3 intravenous injection of $25 \mathrm{mg}$. of parotin caused a transitory decrease of leucocytes followed by its successive increase and the maximum increase appearing two hours after injection and maximum decrease at around eight to ten hours after injection (The percentages of decrease or increase before and 1, 2, 6, 8,10 , and 12 hours after injection were all significant).

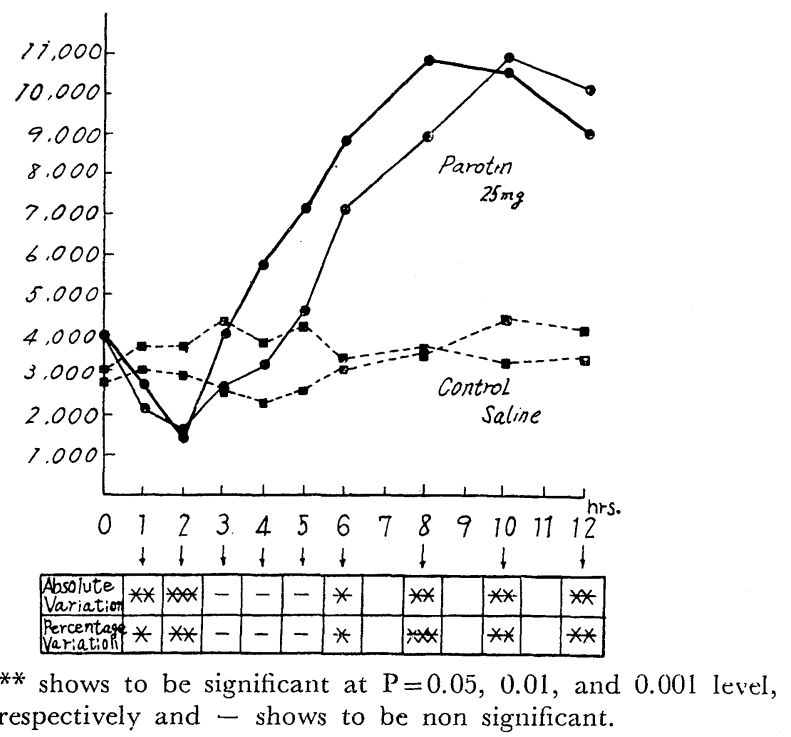

Fig. 3. The effect of parotin injection on the number of circulating leucocytes in rabbits and the result of its significance test at various hours after injection.

A statistical analysis was performed on the variances which were caused by treatment, days, and rabbits differences within the range of parotin doses of 5.4 $25.0 \mathrm{mg}$. and the lineality was examined. It was found by this analysis that concerning the increase response which is considered to be a specific action of parotin, there was no statistically significant difference by treatment. Significant variances by treatment were seen in the transitory decrease at from 2 to 3 hours after injection. The variances by rabbits and days were also significant. The test of lineality showed that only the linear term was significant but not the 
higher order term. In addition, when the values were adjusted according to the body weight and initial value two hours after injection was found to be significant. Such results of statistical analysis on leucocytes change may be due to the fact that the leucocytes themselves are more liable to change than the concentration of protein, that the procedures of measurement were difficult, and that the range of doses used was too wide.

However, this method seems to be favorable as a bioassay method, and further studies are being made on the range of doses and proper conditions.

\section{EXTRAGTION OF PAROTIN FROM THE BOVINE PAROTID GLAND}

According to the 'salivary-gland endocrine theory', the main role of endocrine function is played by the parotid gland, though the active principle is also found in the saliva. Thus the bovine parotid gland was chosen as an easily obtainable resource of the hormone. The isolation was carried out with the reduction of rabbit serum calcium level and promotion of the growth of rat incisors being used as the standard of purification. Extraction with acid alcohol was first performed but the effcetive principle was distributed over numerous fractions and no fraction with a strong effect could be obtained5). Later, after many trials, it was found that extraction with water at a weak alkalinity $(\mathrm{pH} 8.0)$, followed by the precipitation of the effective principle at its isoelectric point ( $\mathrm{pH}$ ca. 5.4) was the most simple and moderate method that gave most powerful product in good yields. Crude parotin is being prepared by this method to date. The yield in mass production of crude parotin by this method is $0.25 \%$ against fresh bovine parotid gland and $0.6 \%$ of the gland removed of fat and of connective tissues. Effect on calcium level reduction of rabbit serum by subcutaneous injection of $7.5 \mathrm{mg}$. $/ \mathrm{kg}$. of the preparation into the animal was approximately one unit $(15 \%$ calcium reduction rate), and the effect on promoting the growth of rat incisors was strongly positive as tested by Dr. Ishii4).

\section{METHOD OF PREPARATION}

The bovine parotid gland was passed through a meat grinder, and placed immediately in 1.5 volumes of weakly alkaline water $(\mathrm{pH} 8.0)$. A small amount of KCN was added, and the surface was covered with a thin layer of toluene. Extraction was carried out for eight hours at room temperature with constant stirring, The residual tissues went through the same process again, and both extracts were put together. The solution was adjusted to $\mathrm{pH}$ 5.4 with $\mathrm{N} \mathrm{HCl}$. After standing over night in an ice box, a precipitate was separated by centrifuge, followed by placing it without drying in the same solvent, the volume of which was $1 / 4$ of the volume of the solvent previously used. This mixture was stirred at room temperature for thirty minutes. The turbid extract was frozen in a refregerator, allowed to thaw at room temperature by placing the frozen mass wrapped in a gauze on a funnel staffed with absorbent cotton. The clear filtrate was adjusted to $\mathrm{pH} 5.4$ with $0.1 \mathrm{~N} \mathrm{HCl}$, allowed to stand over night in an ice box, and centrifuged. The precipitate was washed with several portions of acetone, dehydrated and dried in vacuo and kept in a sulfuric acid desiccator. The same yield was obtained from either adult or young bovine parotid glands or when the freezing was allowed to continue for one month. The same preparation was gained by the same method from acetone-dried parotid gland14). 


\section{PROPERTIES OF GRUDE PAROTIN}

Dr. Ishii, as already mentioned in this paper, proved that parotin promoted the growth of rat incisor tissue. Later Dr. Huse (Gunma University)15) took advantage of the "Okada-Mimura's time marking method by lead acetate vital staining" to prove that parotin promoted calcification of rabbit incisors. In this case, a small dose of parotin (for instance a single subcutancous injection of $25 \mathrm{mg} . / \mathrm{kg}$.) promoted the growth of bones, but on the contrary a larger dose e.g. $50 \mathrm{mg}$. $/ \mathrm{kg}$. single subcutaneous injection gave an adverse effect. This promotion of calcification was also seen in places other than the jaw bone, such as long bone, and teeth cultivated in tibia marrow.

The toxicity of crude parotin is very small and a single subcutaneous injection of $20 \mathrm{mg} . / 18 \mathrm{~g} . \mathrm{b} . \mathrm{wt}$. of crude parotin in mouse failed to cause any appreciable symptoms ${ }^{14)}$. Neither did the repeated injection into rabbits cause any toxic symptoms.

Crude parotin dissolves in water at a $\mathrm{pH}$ above 7.0 and below 3.6, and precipitated out at $\mathrm{pH}$ 5.4-4.4, it does not dissolve in organic solvents. Parotin seemed to undergo denaturation by alcohol at room-temperature because the precipitate obtained by the addition of alcohol to the aqueous solution has a very weak activity but acetone does not change the activity. The efficacy of the aqueous solution does not change by warming the $\mathrm{pH} 8.0$ solution for 1.5 hours but it does diminish in a hydrochloric acid solution when heated at $50^{\circ} \mathrm{C}$, and by prolonged contact with air16)17).

Dried parotin with less than $5 \%$ of moisture can be stored for a long time (e. $g$. four years) in a desiccator at room temperature without remarkable loss of activity but the one containing more than $7 \%$ moisture loses its activity very rapidly by standing in a desiccator at room temperature ${ }^{18)}$. Representative examples are given in the following Table II :

Table II.

\begin{tabular}{|c|c|c|c|c|c|}
\hline $\begin{array}{l}\text { Prepara- } \\
\text { tion }\end{array}$ & Date of test & Dose $/ 2 \mathrm{~kg}$ & Administration & $\begin{array}{l}\text { Serum } \\
\text { calcium } \\
\text { reduction }\end{array}$ & $\begin{array}{l}\text { Water } \\
\text { content }\end{array}$ \\
\hline RPIC & $\begin{array}{lll}\text { First time: } & \text { Aug. } 21 \text { '44 } \\
\text { Second time: } & \text { Sep. 16 '48 } \\
\text { Second time: } & \text { Sep. } 10 \text { '48 }\end{array}$ & $\begin{array}{l}15 \mathrm{mg} \\
15 \mathrm{mg} \\
\end{array}$ & $\begin{array}{l}\text { Subcutaneous injection } \\
\text { Intravenous injection }\end{array}$ & $\begin{array}{l}81.25 \% \\
7.3 \% \\
-\end{array}$ & $10.3 \%$ \\
\hline RPIA & $\begin{array}{lr}\text { First time: } & \text { '44 } \\
\text { Second time: } & \text { Jan. } 12 \text { '48 } \\
\text { Second time: } & \text { Sep.16'48 }\end{array}$ & $\begin{array}{r}15 \mathrm{mg} \\
7.5 \mathrm{mg} \\
-\end{array}$ & $\begin{array}{l}\text { Subcutaneous injection } \\
\text { Intravenous injection }\end{array}$ & $\begin{array}{l}23.21 \% \\
17.5 \% \\
-\end{array}$ & $4.72 \%$ \\
\hline
\end{tabular}

The activity of crude parotin is only slightly reduced by protaminase (at $\mathrm{pH}$ 8.0, $40^{\circ} \mathrm{C}, 2$ hours, 25 times potency preparation of trypsin was used). It was difficult to judge the effect of pepsin on parotin exactly because of a remarkable serum calcium reduction activity of the pepsin used and because of the fact that parotin activity diminished in hydrochloric acid solution. However, no difference in activity was observed after 10 hours digestion of parotin at $50^{\circ} \mathrm{C}$ in comparison with the control hydrochloride solution of parotin ${ }^{16)}$. 
Parotin shows all the color reactions and the precipitation reactions of proteins, and give positive Heller's test in coagulation reactions, not undergoing coagulation by boiling at all $\mathrm{pH}$ ranges except at the isoelectric point $\mathrm{pH}$ 5.4-4.45). The active component is hardly dialyzable through bladder membrane, but prolonged dialysis seems to allow a part of the active protein to go through it ${ }^{17)}$. It has been confirmed by the Wohlgemuth's method that parotin does not have amylase accion ${ }^{17)}$.

The active principle of parotin is salted out from the aqueous solution of crude parotin by neutral salts such as ammonium sulfate, sodium sulfate, and sodium chloride ${ }^{17}$.

\section{PURIFICATION OF GRUDE PAROTIN}

Since the effective component of parotin can be salted out with neutral salts, the fractional precipitation with either ammonium sulfate or sodium sulfateammonium sulfate was applied to the purification of crude parotin ${ }^{2) 18)}$.

\section{FRAGTIONAL PREGIPITATION WITH AMMONIUM SULFATE}

Ammonium sulfate was added to the crude parotin until it reached a $7 \%$ concentration and the considerable amount of inactive insoluble material was precipitated and discarded. Ammonium sulfate was further added to the supernatant until it reached a concentration of 22.5-25\%. The precipitate of the effective component was separated by centrifugation, followed by dialysis. Ammoniurn sulfate was further added to this dissolved precipitate bringing the concentration to $15 \%$, by which the effective component precipitated in crystalline state. This precipitate was dialysed again followed by addition of ammonium sulfate to a concentration of $12.1 \%$. The crystalline precipitate was again obtained. The precipitate was further dialyzed, followed by lyophylization or precipitated once again at the isoelectric point, dialyzed, and lyophylized.

The precipitate from 15\% ammonium sulfate solution was found to be $90 \%$ homogeneous by electrophoresis (Fig. 4) (from here on purity is expressed by electrophoretic purity).

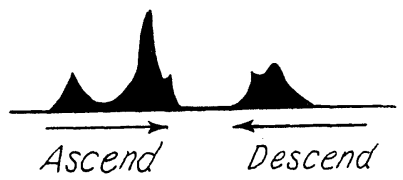

pH 8.0, 0.05 $\mathrm{M}$ phosphate buffer, $20^{\circ} \mathrm{C}, 35 \mathrm{~min}$., and $18.1 \mathrm{mAmp}$, Purity: 85-90\%.

Fig. 4. The precipitate that appeared in crystalline form at 15\% concentratiun ammonium sulfate.

After repeating the precipitation twice from the 15\% ammonium sulfate solution, almost electrophoretically pure homogeneous crystalline precipitate was obtained by adjusting the solution to $12.1 \%$ ammonium sulfate concentration (Fig. 5). 
Table III. Purification of crude parotin (Ammonium sulfate fractionation)

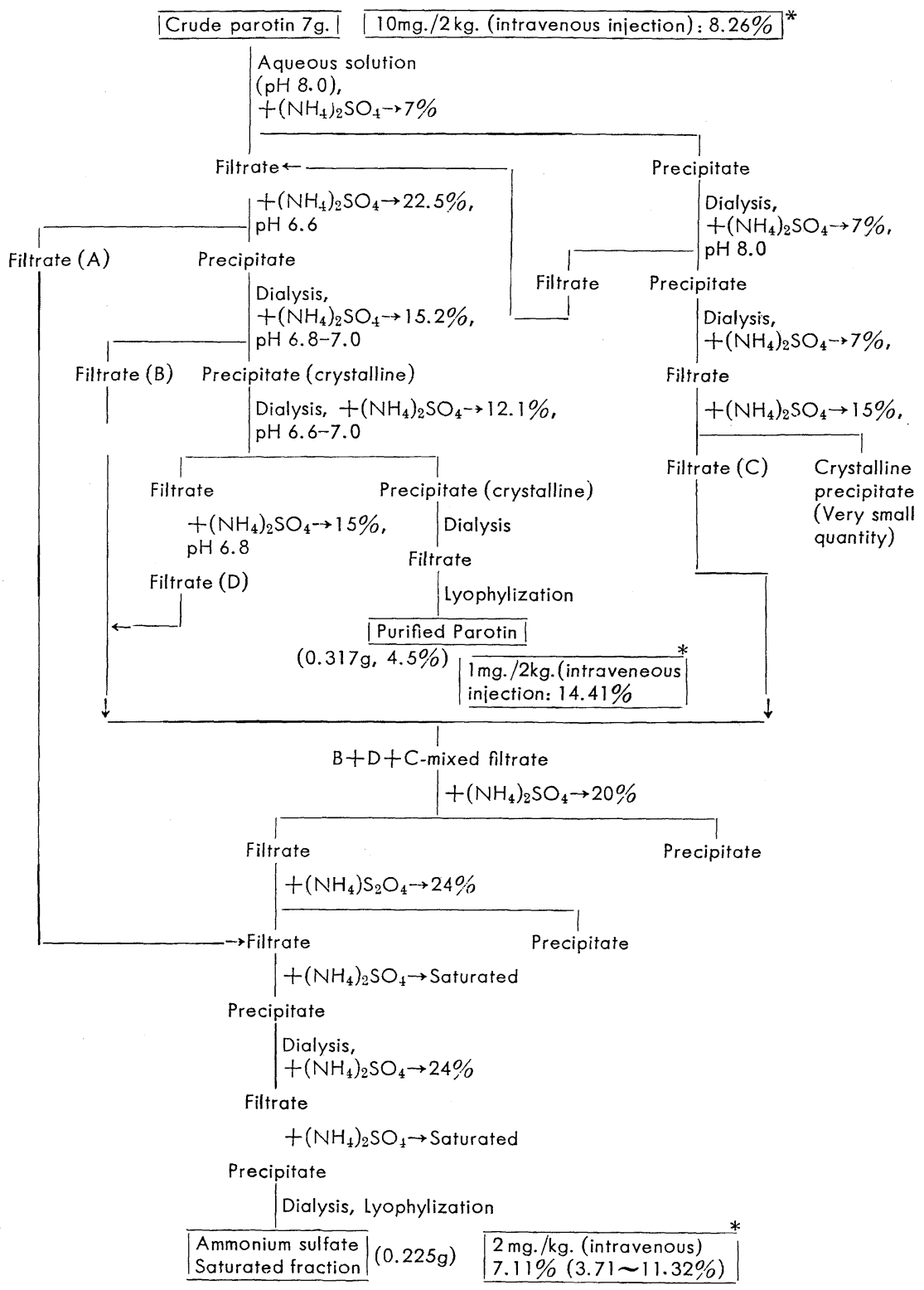

* The activity of the fraction expressed by terms of rabbit serum calcium decreasing rate. 


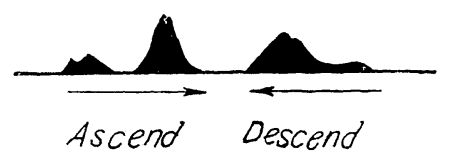

$\mathrm{pH}$ 8.0, 0.05 $\mathrm{M}$ phosphate buffer, $20^{\circ} \mathrm{C}, 38 \mathrm{~min} ., 18.1 \mathrm{mAmp.}$.

Purity: nearly homogeneous.

Fig. 5. Crystals obtained by the recrystallizations of the crystalline precipitate that appeared at $15 \%$ concentration of ammonium sulfate, at $15 \%$,

at $12 \%$ concentration of the same.

A more pure preparation is obtained by bringing the supernatant of the first $7 \%$ solution to $\mathrm{pH} 5.4$ instead of adjusting it to a $25 \%$ ammonium sulfate solution, followed by the same fractionation with ammonium sulfate, successive dialysis, and final precipitation at $\mathrm{pH}$ 5.419). The fraction at each stage of ammonium sulfates fractionation was tested for purity by electrophoresis.

EB-1 (pH 5.4-Precipitate)

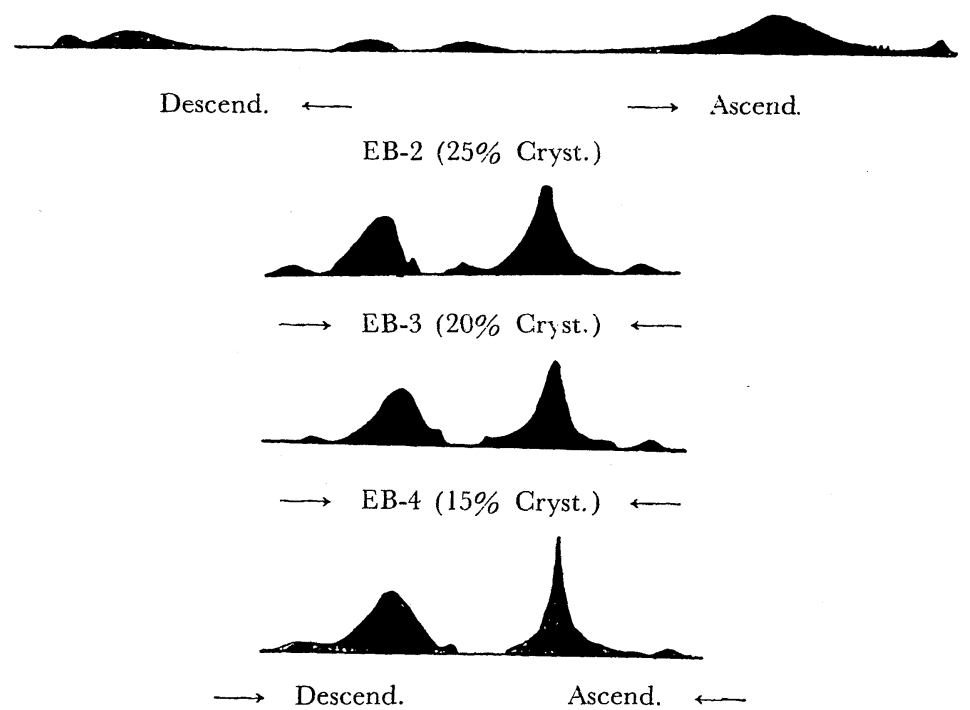

$1 \%$ solution, pH $8.0,0.05 \mathrm{M}$ phosphate buffer, $15^{\circ} \mathrm{C}, 58 \mathrm{Volt}, 60 \mathrm{~min}$.

Purity: EB-1, 68.0\%; EB-2, 96.4\%; EB-3, 96.4\%; EB-4, 98.5\%, respectively.

Fig. 6. The electrophoretic patterns of the fractions at each stage of ammonium sulfate tractionation in the process of parotin purification.

As shown in Fig. 6, the precipitates from 25\% ammonium sulfate (EB-2) was 96.4\% pure, the one from 20\% solution (EB-3) was also 96.4\%, and the final precipitate from 15\% solution (EB-4) was $98.5 \%$. The purity of the original crude parotin (EB-1) used for this fractionation was $68.0 \% 19$. The precipitate from a $22.5 \%$ solution of ammonium sulfate was collected, dissolved in water, and ammonium sulfate was added to this solution until it reached $24 \%$. After repeating this precipitation from $24 \%$ ammonium sulfate solution, the supernatant 
was saturated with ammonium sulfate. The precipitate obtained here (Fig. $21 \mathrm{c}$ ) was found to be highly toxic by intravenous injection in rabbit, and this fraction possessed almost no activity. The activity per gram of crystalline precipitates (Fig. 7) trom $12.1 \%$ solution was about 10 times stronger than that of crude parotin ${ }^{2)}$.

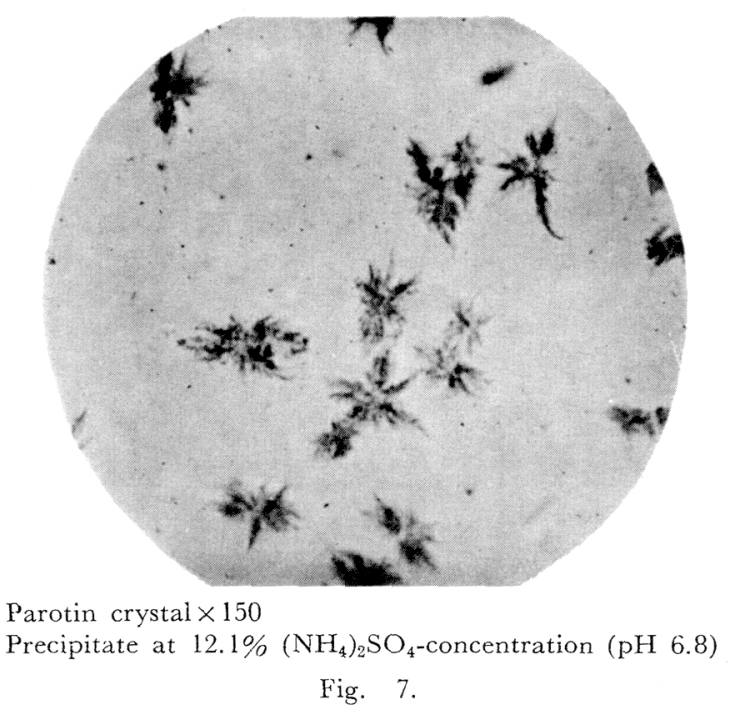

The yield was $4.5 \%$ of crude parotin. The parotin preparation being used at present for study is the precipitates from the $20 \%$ ammonium sulfate solution. The yield of such a preparation in mass production is $3.0 \%$ of crude parotin and $0.02 \%$ of original material (parotid gland removed of fat and attached tissues).

\section{FRACTIONAL PREGIPITATION WITH SODIUM SULFATE- AMMONIUM SULFATE}

The purification was attempted as shown in Table IV by combined fractionation with ammonium sulfate and sodium sulfate crystalline precipitate was obtained from a $15 \%$ and $12 \%$ ammonium sulfate solution, but the yield was extremely poor compared to that of the ammonium sulfate fractionation. A fractional precipitation with sodium sulfate alone failed to yield any crystalline precipitate ${ }^{18}$. 
Table IV. Purification of crude parotin (Sodium sulfate-ammonium sulfate fractionation)

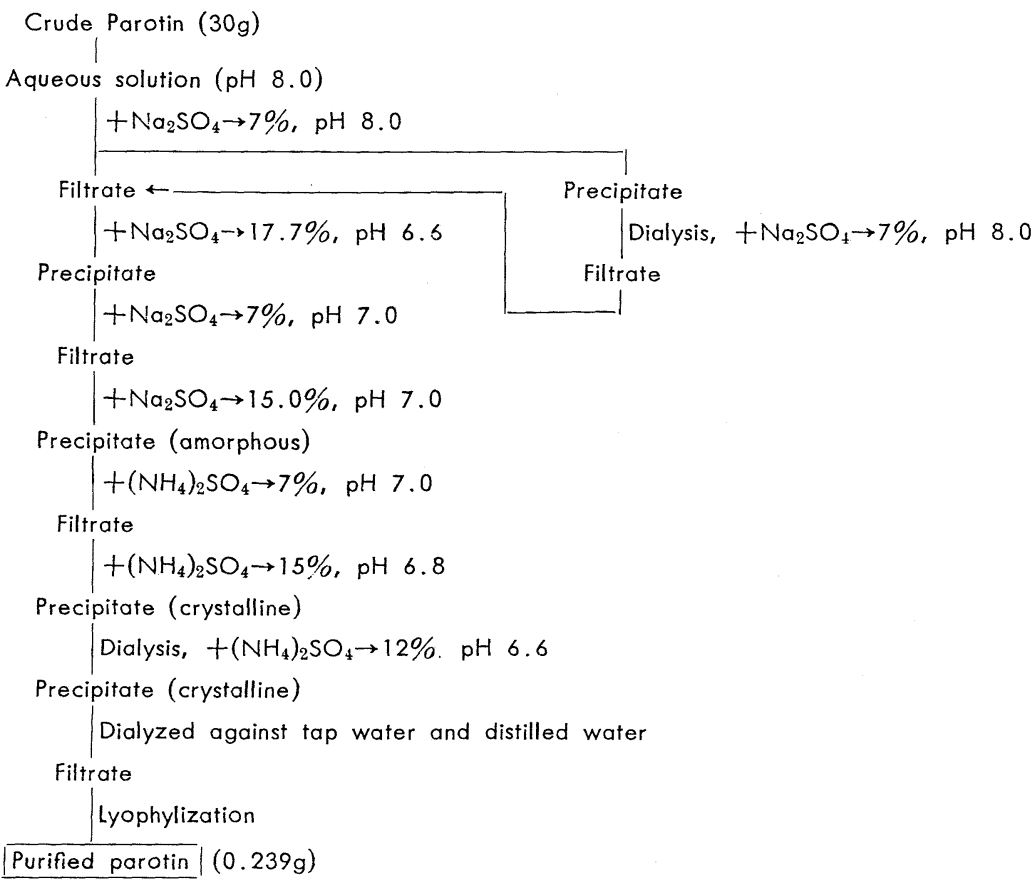

\section{PHYSICO-CHEMICAL PROPERTIES OF PURIFIED PAROTIN}

The following data have obtained as to physico-chemical properties of homogeneous purified parotin (see Fig. 5)21).

Isoelectric point

Specific rotation, $[\alpha]_{\mathrm{D}}^{23}$

Specific viscosity, $\mu_{\mathrm{sp}}$ Intrinsic viscosity, $[\mu]$

Axial ratio, b/a

Diffusion constant, $\mathrm{D}_{20}, \mathrm{w}$

Partial specific volume, $V_{1}$

Dissymmetric constant, $\mathrm{f} / \mathrm{f}_{0}$

Molecular weight, $\mathrm{M}$

Long axis

Short axis
pH 5.7 (Antimony electrode)

-85.7 ( $\mathrm{pH} 7.8$ aqueous solution, $\mathrm{c}=6.18 \mathrm{mg} .(\mathrm{cc} ., 1=1 \mathrm{dm}$.)

0.12 (Ostwald's viscosimeter) 15.9

11 (Polson's formula)

$2.21 \times 10^{-7}$ (Neurath-free diffusion cell)

0.753

1.49

800,000

$634.0 \AA$

$57.6 \AA$

\section{ABSORPTION SPECTRUM OF PURIFIED PAROTIN}

As shown in Fig. 8. parotin shows in $\mathrm{pH} 7.0$ aqueous solution ultraviolet absorption maximum at $277 \pm 0.5 \mathrm{~m} \mu$ (Beckman spectrophotometer), but in the alkaline solution it shifts to longer wave length.

The ultraviolet absorption spectra of the foregoing parotin preparations (cf, 
preceding section), EB-1 (original crude parotin, purity 68.0\%), EB-2 (purity, 96.4\%), and EB-4 (purity 98.6\%) were studied ${ }^{19}$ ). Each preparation was dissolved in $\mathrm{pH} 7.0$ aqueous solution and tested by Beckman Spectrophotometer. The wave length at which maximum absorption occurred, the extinction ( $E_{\mathrm{Icm}}^{1 \%}$ ) at that wave length, and the relationship between concentration and extinction were

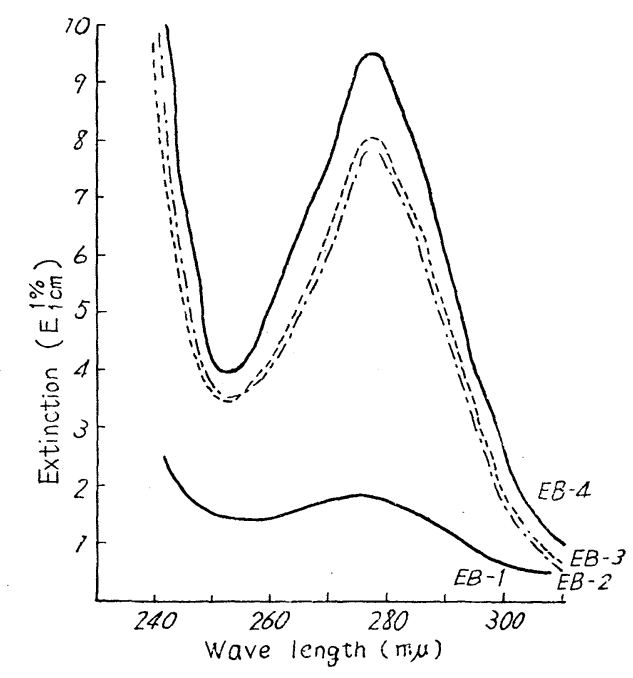

EB-1: 68.0\%; EB-2: 96.4\%; EB-3: 96.4\% and EB-4: 98.6\% purity, respectively.

Fig. 8. Ultraviolet absorption spectra of parotin solutions ( $\mathrm{pH} 7.0$ ) with various purity.

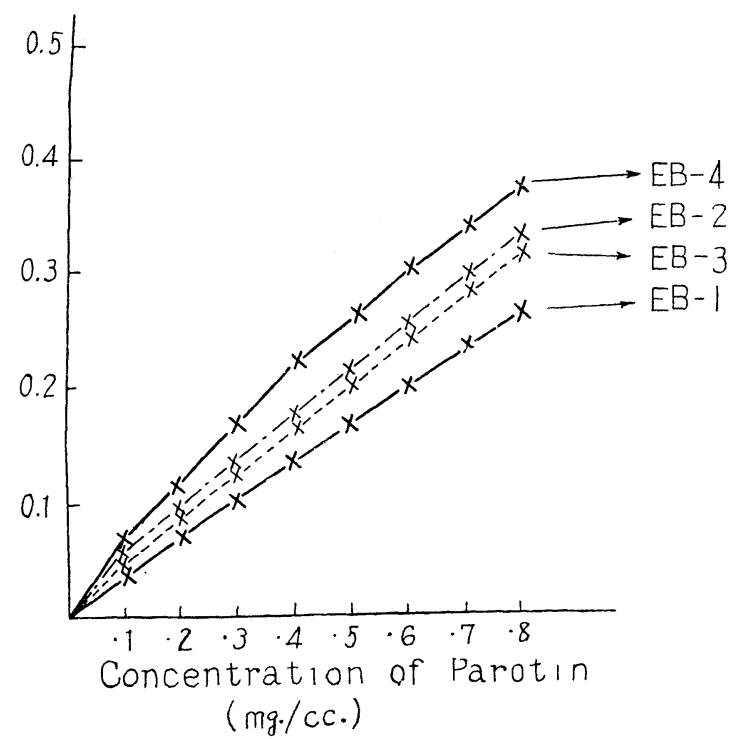

Fig. 9. Relationship between the ultraviolet extinction at $277 \mathrm{~m} \mu$ and the concentration of parotin (mg./cc.) 
studied in detail. The absorption curves of the $\mathrm{pH} 7.0$ solution of all four preparations showed a maximum absorption at $277 \pm 0.5 \mathrm{~m} \mu$ (Fig. 8).

The extinction $\left(\mathrm{E}_{1 \mathrm{~cm}}^{1 \%}\right)$ at that wave length increased as the purity of parotin increased. As shown in Fig. 9, the concentration of parotin shows a linear relation with extinction at $277 \mathrm{~m} \mu$ within the concentration range of $0.1-0.8 \mathrm{mg}$. $/ \mathrm{cc}$. The maximum absorption of constituent amino acids was tested to determine if the amino acids in the parotin molecule is responsible for its maximum absorption at $277 \mathrm{~m} \mu$. The maximum of the absorption of each of tyrosine, methionine, cystine, and tryptophan, and their mixture in the same ratio as that of parotin constituent, at $\mathrm{pH} 7.0$ were found at $275 \mathrm{~m} \mu$ in tyrosin and the amino acid mixture, $279 \mathrm{~m} \mu$ in tryptophan, and methionine and cystine failed to show absorption maximum. These values are apparently different from the maximum of parotin at $277 \mathrm{~m} \mu$ though this difference may be due to the peptide bond in parotin.

\section{POLAROGRAM OF PURIFIED PARO'TIN}

The same preparations of parotin (EB-1, EB-2, EB-3, and EB-4) which were used for the absorption spectrum were examined by polarograph in ammonia-

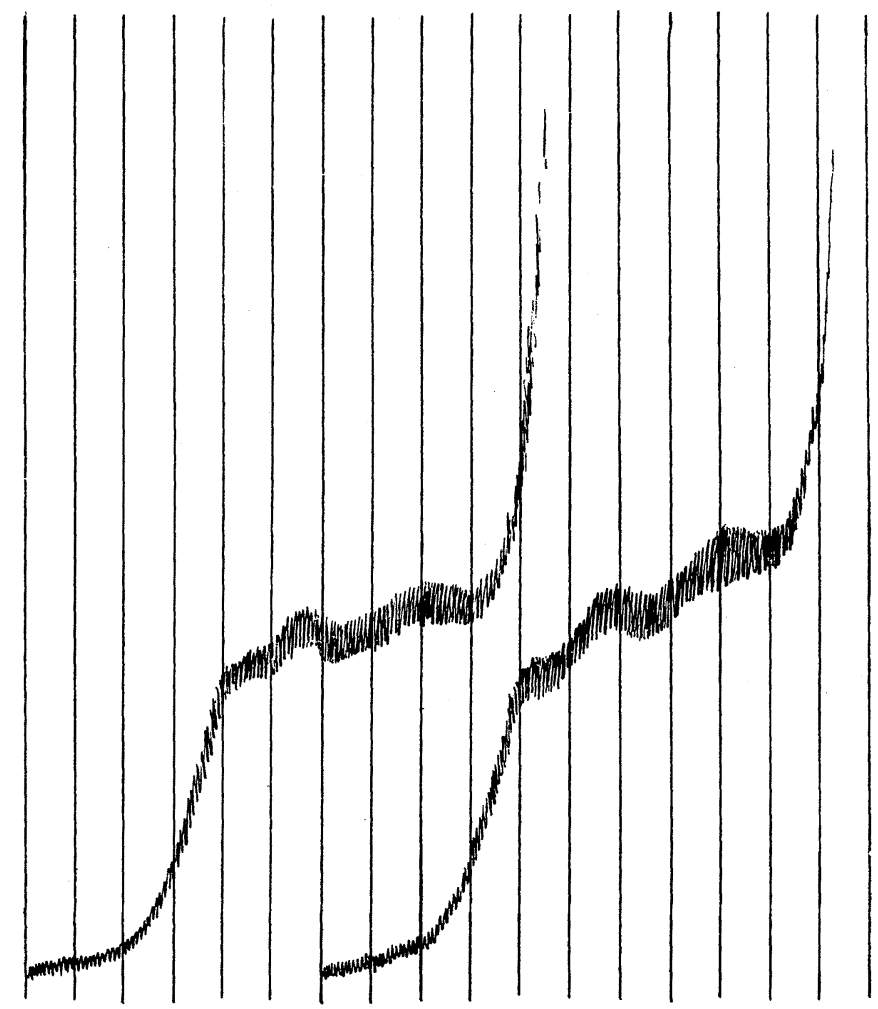

left : $0.05 \mathrm{mg} . / \mathrm{cc}$. parotin; right: $0.15 \mathrm{mg} . / \mathrm{cc}$. parotin.

Fig. 10. The polarogram of parotin in $0.2 \mathrm{~N}$ ammonia- $0.25 \mathrm{~N}$ ammonium chloride buffer solution containing $0.01 \mathrm{~N} \mathrm{CoCl}_{2}$. 
ammonium chloride buffer solution, in the presence of $\mathrm{Co}^{++}$or $\mathrm{Co}^{+++}$, at a voltage of $-0.8 \sim-2.0 \mathrm{~V}$. Polarogram having three waves were obtained as shown in Fig. $10\left(\mathrm{Co}^{++}\right)$and Fig. $11\left(\mathrm{Co}^{+++}\right)$. In the case of $\mathrm{Co}^{+++}$the third wave become the maximum.

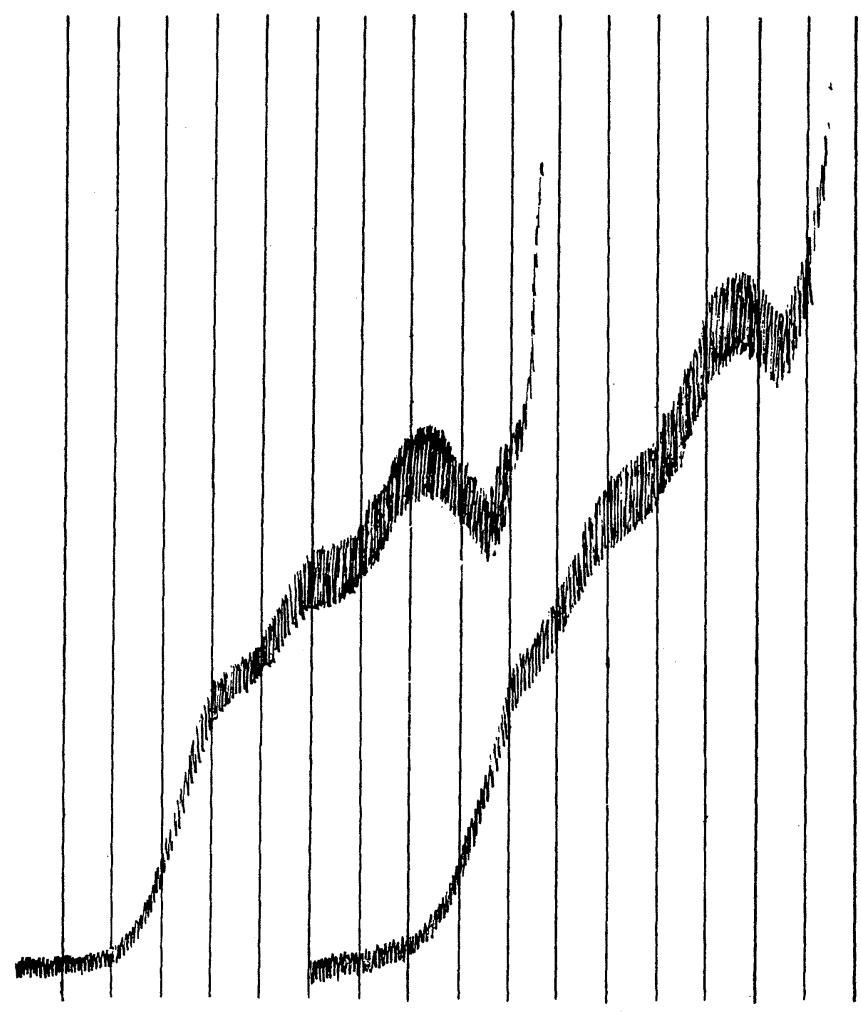

felt : $0.05 \mathrm{mg} . / \mathrm{cc}$. parotin; right: $0.15 \mathrm{mg} . / \mathrm{cc}$. parotin.

Fig. 11. The polarogram of parotin in $0.2 \mathrm{~N}$ ammonia- $0.25 \mathrm{~N}$ ammonium chloride buffer solution containing $0.01 \mathrm{~N} \mathrm{Co}\left(\mathrm{NH}_{3}\right)_{6} \mathrm{Cl}_{3}$.

The half-wave potentials of each wave are shown in Table V.

Table V.

\begin{tabular}{lcc}
\hline \hline \multirow{2}{*}{ Wave No. } & \multicolumn{2}{c}{ E 1/2 (S.C.E.) } \\
\cline { 2 - 3 } & Co ${ }^{++}$Electrolyte & Co \\
\hline First wave & -1.10 Volt & -1.13 Volt \\
Second wave & -1.35 Volt & -1.35 Volt \\
Third wave & -1.57 Volt & -1.60 Volt (Maximum wave) \\
\hline
\end{tabular}

Of these three waves, the first one corresponds to the potential of cobalt decomposition potential and is therefore due to $\mathrm{Co}^{++}$or $\mathrm{Co}^{+++}$. The third one is the same as the second wave obtained in the polarogram of cystine under the same conditions. In the case of cystine two waves are obtained, the first of which 
corresponds to the precipitation potential of cobalt and the second corresponds to the third wave of parotin. When cystine was added to parotin in various portions, the second wave of parotin did not change but the wave of parotin may be due to the presence of -S-S-group in the parotin molecule. In order to examine the third wave, 20 cystine analogous compounds were determined by polarographic analysis. It shows the third wave only in the compound which has $-\mathrm{S}-\mathrm{S}-$ or $-\mathrm{SH},-\mathrm{NH}_{2}$ and $-\mathrm{COOH}$ groups such as cystine, homocystine and homocysteine. Polarograms of each amino acid constituent of parotin, such as tyrosine, methionine, cystine, and tryptophan, and a mixture of these amino acids in the same ratio as that of parotin, showed the half-wave potentials, as shown in Table VI.

Table VI.

\begin{tabular}{|c|c|c|c|c|}
\hline \multirow{3}{*}{ Amino acid } & \multicolumn{4}{|c|}{ E 1/2 (S.C.E.) } \\
\hline & \multicolumn{2}{|c|}{$\mathrm{Co}^{++}$Electrolyte } & \multicolumn{2}{|c|}{$\mathrm{Co}^{+++}$Electrolyte } \\
\hline & First wave & Second wave & First wave & Second wave \\
\hline & (Volt) & (Volt) & (Volt) & (Volt) \\
\hline Tyrosine & -1.20 & - & -1.22 & - \\
\hline Methionine & -1.23 & - & -1.20 & - \\
\hline Cystine & -1.15 & -1.66 & -1.13 & -1.60 \\
\hline Tryptophan & -1.14 & - & -1.13 & - \\
\hline Mixture & -1.18 & -1.66 & -1.18 & -1.60 \\
\hline
\end{tabular}

Since the wave corresponding to the potential of the second wave in parotin did not appear in these, the second wave was considered to be specific to the parotin ${ }^{19)}$.

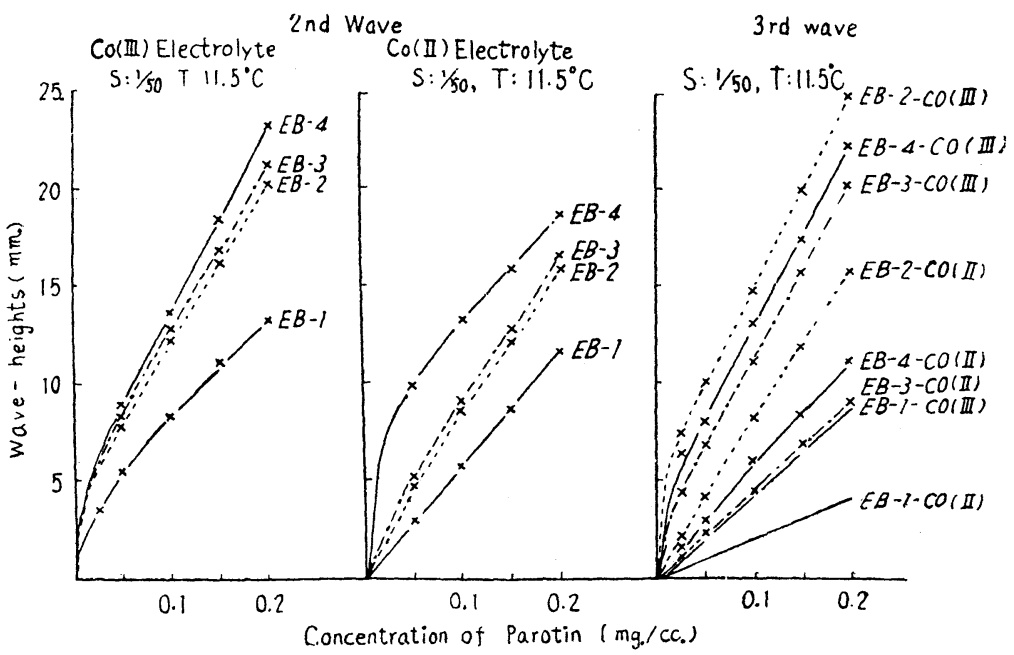

Fig. 12. Relation between polarographic 2 nd and $3 \mathrm{rd}$ wave-heights and the concentration of parotin

Fig. 12 shows the relation between wave height and concentration of the preparations EB-1 4. The linear relation was seen within the concentration 
range of $0.05-0.15 \mathrm{mg} . / \mathrm{cc}$. of parotin, and at the same concentrations the height of the second wave increased with the increase of the purity of the preparation. Such a phenomenon was not observed in the third wave19).

\section{CHEMIGAL PROPERTIES OF PAROTIN}

Parotin of $92 \%$ purity (Fig. 13) was hydrolyzed by heating with $20 \% \mathrm{HCl}$ for 40 hours, and the acid was removed by evaporation under diminished pressure and the residue was dissolved in $0.1 \mathrm{~N} \mathrm{HCl}$ to $1 \%$ concentration. This hydrolyzate was submitted to paper chromatography with No. 50. Toyo Roshi filter paper by the one-dimensional dipping method and the two-dimensional ascending method, using ninhydrin, sodium 1,2-naphthoquinone-4-sulfonate, KI $-\mathrm{H}_{2} \mathrm{PtCl}_{6}$, diazobenzenesulfonic acid and Sakaguchi's reagent as the coloring reagents ${ }^{20)}$.

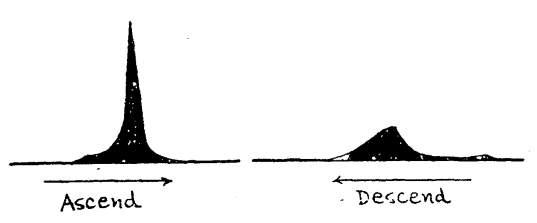

pH $8.0,0.05 \mathrm{M}$ phosphate buffer, $13^{\circ} \mathrm{C}$, 120 min., $80 \mathrm{~V}, 7 \mathrm{~mA}$. purity: $92 \%$

Fig. 13. Electrophoretic pattern of parotin.

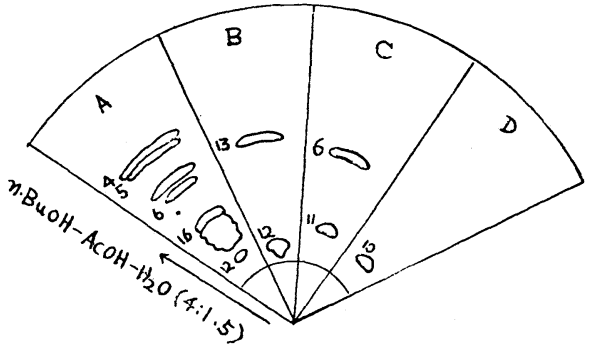

A: Na 1, 2-naphichoquinone-4-sulfonate,

B: $\mathrm{KI}-\mathrm{H}_{2} \mathrm{PtCl}_{6}$, C: Diazo reaction, D: Sakaguchi reaction. 4. Leu, 5. Phe, 6. Tyr, 10. Arg, 11. His, 12. Gys, 13. Met, 16. Pro.

Fig. 14. Gircular paper chromatogram of parotin hydrolyzate.

Fig. 14 shows the result of the circular paper chromatogram developed with solvent mixture of $\mathrm{N}$ butanol-acetic acid-water (4:1:5), Fig. 15 shows the result of the two-dimensional paper chromatogram using the mixture of $\mathrm{N}$ butanolacetic acid-water (4:1:2) and phenol-0.1\% ammonia (4:1), and Fig. 16 shows the result of two-dimensional paper chromatogram using $\mathrm{N}$ butanol-acetic acid-water (4:1:5) and $\mathrm{N}$ butanol saturated with water as developing agent. These results revealed that parotin hydrolyzate contains 17 amino acids, namely, glycine, alanine, valine, leucine, phenylalanine, tyrosine, aspartic acid, glutamic acid, lysine, arginine, histidine, cystine, methionine, serine, threonine, proline, and tryptophan ${ }^{20)}$. The amounts of these amino acids were $3.64 \%$ tyrosine, $1.09 \%$ tryptophan (Folin-Marenzi's method) and $1.13 \%$ cystine ${ }^{21}$. The amount of sulfur was $0.77 \%$, it contained neither the $-\mathrm{SH}$ group nor cysteine, and the content of methionine was calculated as $2.15 \%$ by subtracting the content of cystine-sulfur from the total amount of sulfur ${ }^{21)}$. Phosphorus and nitrogen from the amino group composed $0.06 \%$ and $0.6 \%$ of parotin respectively ${ }^{21)}$. The amino-nitrogen 


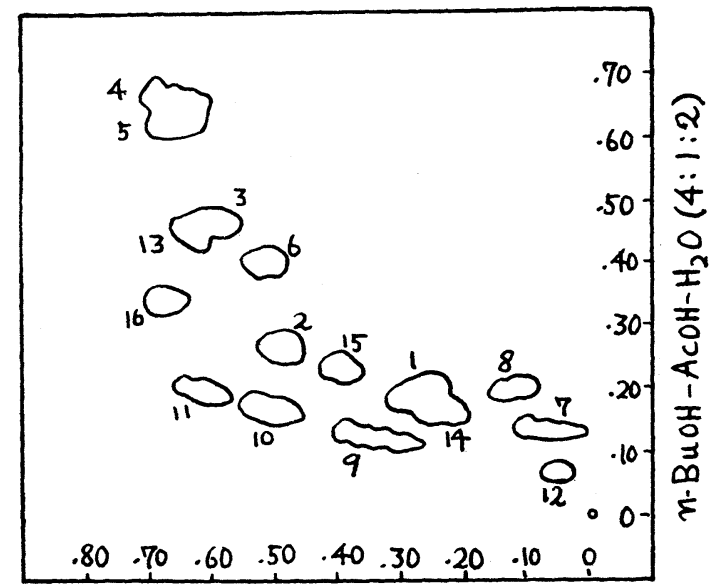

Phenol- $0.1 \% \mathrm{NH}_{3}(4: 1)$

1. Gly, 2. Ala, 3. Val, 4. Leu, 5. Phe, 6. Tyr, 7. Asp, 8. Glu, 9. Lys, 10. Arg, 11. His, 12. Cys, 13. Mer, 14. Ser, 15. Thr, 16. Pro.

Fig. 15. Two-dimensional chromatogram of parotin hydrolyzate.

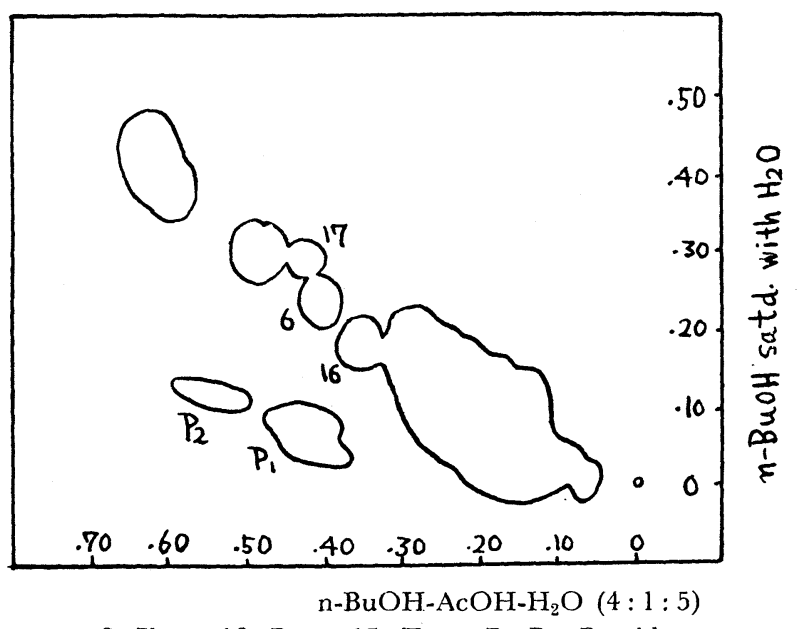

6. Tyr, 16. Pro, 17. Try, $\mathbf{P}_{1}, \mathrm{P}_{2}$. Peptide.

Fig. 16. Two-dimensional chromatogram of parotin hydrolyzate.

increased to $3.8 \%$ when toluene was saturated in the $1 \%$ parotin solution and allowed to stand in closely stoppered container for eight months through mid-summer21). The result of elementary analysis gave the following values: carbon, 50.84\%; hydrogen, 7.31\%; nitrogen, $14.53 \%$ and the amount of ash was negligible. Homogeneous parotin was used for these analysis ${ }^{21)}$. The parotin preparation gives a positive Molisch's reaction but showed negative pentose reaction (phloroglucinol-HCl and orcinol-HCl reaction)22). Although it is advisable to separate the sugar moiety to identify the kinds of sugar present, the following method was used for preliminary identification of sugars because of 
the insufficient amount of parotin ${ }^{22)}$. The hydrolyzate of parotin of $93 \%$ purity was examined for hexose by the carbazole-sulfuric acid method ${ }^{23}$.

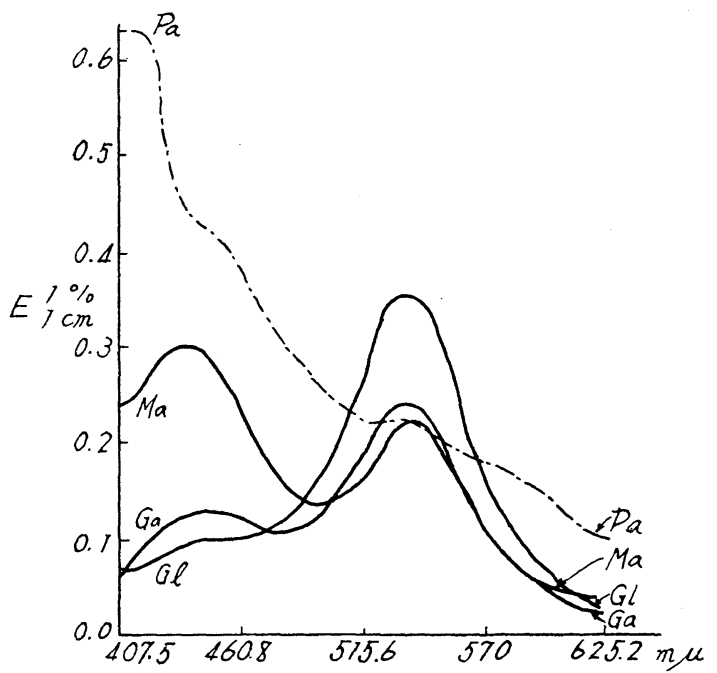

$\mathrm{Gl}$ : glucose $100 \mathrm{microgram} / \mathrm{cc}$; $\quad \mathrm{Ga}$ : galactose $114.9 \mathrm{microgram} / \mathrm{cc}$;

$\mathrm{Ma}$ : mannose 105.5 microgram/cc.; $\mathrm{Pa}$ : parotin purified $10.05 \mathrm{mg} . / \mathrm{cc}$.

Fig. 17. Absorption spectra of the glucose, mannose and parotin solution treated by carbazole- $\mathrm{H}_{2} \mathrm{SO}_{4}$ method.

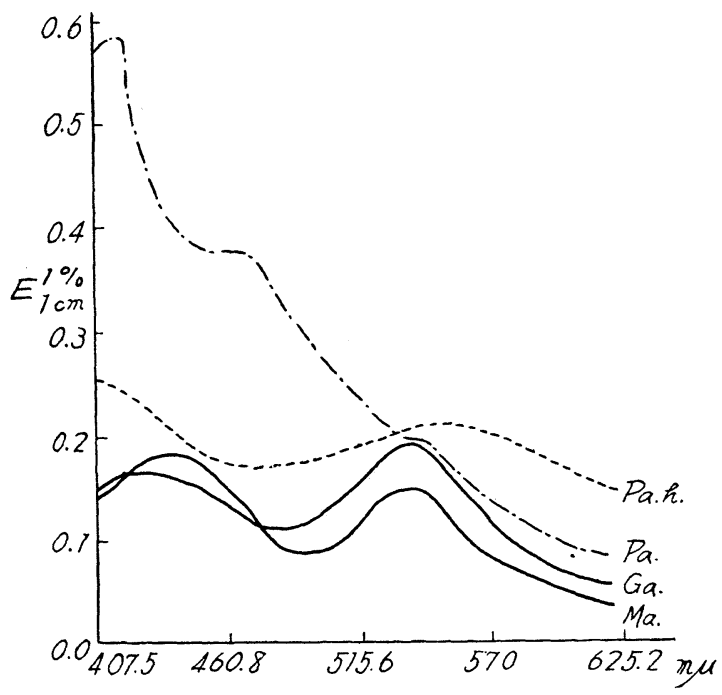

$\mathrm{Ga}$ : galactose 80.43 microgram/cc.; Ma: mannose 73.85 microgram/cc.; $\mathrm{Pa}$ : parotin purified 10.33 $\mathrm{mg}$./cc; Pa.h.: hydrolyzate of parotin purified $10.705 \mathrm{mg} . / \mathrm{cc}$. (as starting material).

Fig. 18. Absorption spectra of the galactose, mannose, parotin and parotinhydrolyzate treated by carbazole- $\mathrm{H}_{2} \mathrm{SO}_{4}$ method. 
Fig. 17 and 18 show the extinction curve between $407.5-625.2 \mathrm{~m} / \mu$ of the carbazole-sulfuric acid color reaction of parotin, parotin hydrolyzate, glucose, mannose, and galactose.. Each sugar shows its characteristic curve. Although parotin itself has a quite different curve from those of the sugars, parotin hydrolyzate showed the curve very similar to those of the sugars (Fig. 18). The parotin hydrolyzate in general shows a curve different from that of either mannose or galactose and this may be due to the presence of a non-sugar substance which reacts with carbazole. The ratio $\mathrm{E}_{520} / \mathrm{E}_{420}$ of galactose, mannose, and parotin hydrolyzate were: galactose, 0.99; mannose, 0.76; and parotin hydrolyzate, 0.74, respectively. The close values of the parotin hydrolyzate and mannose suggests the view that sugar in parotin may be mannose. There is an effect of the interaction between the non-sugar substance and carbazole, in the parotin hydrolyzate curve (Fig. 18), it seems rather dangerous to conclude so. It my be mannose but it is at least clear that the sugar moiety of parotin is not glucose from either its appearance, absorption spectrum, or $\mathrm{E}_{520} / \mathrm{E}_{420}$ value ${ }^{22)}$.

Assuming that the sugar moiety of parotin is mannose, the quantitative determination of the sugar by naphthole-sulfuric acid method ${ }^{24)}$ was carried out ${ }^{25}$. It was found that the parotin preparation of 93\% purity (Fig. 19) contained

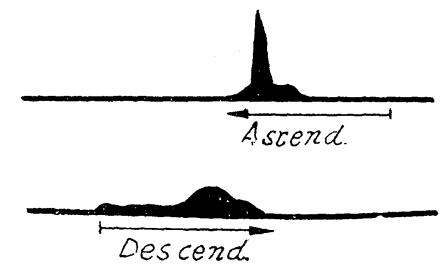

$\mathrm{pH} 7.9,0.05 \mathrm{M}$ phosphate buffer, 12.0 mAmp., $17^{\circ} \mathrm{C}$.

Purity: approximately 93\%.

Diagram shows the existence of two components.

Fig. 19. Electrophoretic patterns of parotin preparation purified fractional precipitation with ammonium sulfate.

$0.73 \%$ of the sugar (as mannose). In order to clarify whether this sugar was from parotin itself or from impure occlusion, the sugar was determined in the impure crude preparation of parotin recovered from the supernatants of parotin

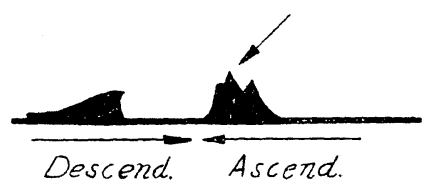

$\mathrm{pH} 7.9,0.05 \mathrm{M}$ phosphate buffer, $12.0 \mathrm{mAmp} ., 17^{\circ} \mathrm{C}$.

The existence of three components are illustrated in the ascending pattern.

The content of the effective component (indicated in middle peak by arrow) is approximately $45 \%$.

The content of the component of smaller mobility than that of the effective component is approximately $38 \%$ (right side peak).

The content of the greater mobility is approximately $17 \%$ (left side peak).

Fig. 20. Electrophoretic patterns of the precipitate appeared when the supernatant solutions which were obtained by fractional precipitations of $\mathrm{pH}$ 5.4-precipitate with ammonium sulfate, were adjusted to the isoelectric points. 
purification. This preparation was electrophoretically 45\% pure (Fig. 20). Of the two impurities, the content of the one with less mobility was $38 \%$, and this was the same as the impurity $7 \%$ contained in the preparation of $93 \%$ purity (Fig. 19). The other with large mobility occupied $17 \%$ and was specific only to this preparation. From these values of sugar content and the constituent of each preparation, the range of possible amount of sugar in these preparations was calculated. It was found that the percentage of sugar content in active component is between $0.48 \%$ and $0.79 \%$, and never becomes zero. Thus, even the most purified preparation would contain this amount of sugar. It is hoped that further study will be made along this line after it becomes possible to obtain a large amount of preparations which would be found homogeneous not only by electrophoresis but also by ultracentrifuge and solubility test. It is highly probable that parotin contains no hexosamine or, if it does, in a very minute amount25) (Nilson's method ${ }^{26)}$ ).

As shown in Table VII the aqueous solution of parotin is more labile in acid than in alkaline state at a room temperature. The neutral solution of parotin

Table VII.

\begin{tabular}{|c|c|c|c|c|}
\hline $\begin{array}{l}\mathrm{pH} \text { of } \\
\text { solution }\end{array}$ & $\begin{array}{l}\text { Temp. } \\
\left({ }^{\circ} \mathrm{C}\right)\end{array}$ & $\begin{array}{l}\text { Duration } \\
\text { of standing } \\
\text { (heating) }\end{array}$ & $\begin{array}{l}\text { Average serum } \\
\text { Ca-reduction }\end{array}$ & Notes \\
\hline 7.6 & in refrigerator & 18 & 15.3 & in saline solution \\
\hline 1.08 & $23^{\circ}$ & 17 & 6.5 & $0.1 \mathrm{~N} \mathrm{HCl}$ solution \\
\hline 2.37 & $24^{\circ}$ & 19 & 8.4 & $\mathrm{NCH}{ }_{3} \mathrm{COOH}$ solution \\
\hline 11.2 & $22^{\circ}$ & 17 & 10.1 & $0.1 \mathrm{M} \mathrm{Na} \mathrm{CO}_{3}$ solution \\
\hline 2.0 & $40^{\circ}$ & 2 & 6.8 & $0.1 \mathrm{~N} \mathrm{CH}{ }_{3} \mathrm{COOH}, 5 \mathrm{~N} \mathrm{HCl}$ solution \\
\hline 7.6 & $40^{\circ}$ & 1 & 3.9 & $0.1 \mathrm{~N}$ phosphate-buffer \\
\hline 7.6 & $40^{\circ}$ & 2 & 7.8 & " " \\
\hline 7.6 & $60^{\circ}$ & 2 & 6.5 & "l \\
\hline 7.6 & boiling water & $1 / 2$ & 1.7 & $\|$ \\
\hline
\end{tabular}

loses part of its activity even at $40^{\circ} \mathrm{C}$. and the activity is completely lost by boiling for 0.5 hour ${ }^{21)}$. It seems that the activity of parotin decreases when its aqueous solution is dialyzed or stored in an ice box for many days (see Table $\mathrm{X}$ (II and XIV)27).

In order to study the effects of the free amino radical, tyrosine phenyl radical, and disulfide bond, in the parotin molecule on the serum calcium reduction

Table VIII. Action of ketene on parotin

\begin{tabular}{|c|c|c|c|c|c|c|}
\hline \multirow{3}{*}{$\begin{array}{c}\text { Temperature } \\
\text { of treatment } \\
{ }^{\circ} \mathrm{C}\end{array}$} & \multirow{3}{*}{$\begin{array}{l}\text { Time of } \\
\text { treatment } \\
\text { min. }\end{array}$} & \multirow{2}{*}{\multicolumn{2}{|c|}{$\frac{\mathrm{pH}}{\text { (acetate buffer) }}$}} & \multirow{3}{*}{$\begin{array}{c}\text { Free } \mathrm{NH}_{2} \\
\text { groups } \\
\text { covered } \\
\%\end{array}$} & \multicolumn{2}{|c|}{ Assays } \\
\hline & & & & & \multirow{2}{*}{$\begin{array}{l}\text { Dose* intraven- } \\
\text { ous. mg. } / 2 \mathrm{~kg} \text {. } \\
\text { body wt. }\end{array}$} & \multirow{2}{*}{$\begin{array}{c}\text { Mean rate of } \\
\text { Ca-dec. } \% \\
\text { (5 rabbits) }\end{array}$} \\
\hline & & Start & Final & & & \\
\hline 23 & 15 & 5.6 & 5.0 & 94 & 3.06 & 5.3 \\
\hline 19 & 5 & 5.6 & 5.2 & 90 & 3.06 & 6.74 \\
\hline 0 & 5 & 5.6 & 5.2 & 64 & 3.0 & 6.41 \\
\hline 0 & 3 & 5.6 & 5.2 & 48 & 3.0 & 6.49 \\
\hline \multicolumn{4}{|c|}{ Untreated solution } & 0 & 3.0 & 15.3 \\
\hline
\end{tabular}

\footnotetext{
* The solution was adjusted to $\mathrm{pH} \mathrm{7.2.}$
} 
Table IX. Action of nitrous acid and formaldehyde on parotin

\begin{tabular}{ccccccc}
\hline \hline Reagents & $\begin{array}{c}\text { No. of } \\
\text { experiment }\end{array}$ & $\begin{array}{c}\text { Temperature } \\
\text { of } \\
\text { treatment } \\
{ }^{\circ} \mathrm{C}\end{array}$ & $\begin{array}{c}\text { Time of } \\
\text { treatment } \\
\text { min. }\end{array}$ & $\begin{array}{c}\text { Dose } \\
\text { mg./2kg. } \\
\text { body wt. }\end{array}$ & $\begin{array}{c}\text { Mean rate of } \\
\text { Ca-dec. } \% \\
\text { (5 rabbits }\end{array}$ \\
\hline Nitrous acid & $1^{*}$ & 20 & 30 & 3.0 & 9.38 \\
\hline Formaldehyde & 11 & $27 \sim 28$ & 60 & 3.0 & 2.40 \\
\hline Untreated & 1 & $20 \sim 21$ & 30 & 3.0 & 4.14 \\
\hline
\end{tabular}

* The solution seems to have been insufficiently stirred at the reaction.

Table X. Action of iodine of parotin

\begin{tabular}{|c|c|c|c|c|c|}
\hline \multirow[b]{2}{*}{$\begin{array}{c}\text { No. of } \\
\text { experiment }\end{array}$} & \multirow[b]{2}{*}{$\begin{array}{l}\mathrm{pH} \text { of } \\
\text { solution }\end{array}$} & \multirow{2}{*}{$\begin{array}{c}\text { Temperature } \\
\text { of } \\
\text { treatment } \\
{ }^{\circ} \mathrm{C}\end{array}$} & \multirow[b]{2}{*}{$\begin{array}{l}\text { Time of } \\
\text { treatment } \\
\text { hrs. }\end{array}$} & \multicolumn{2}{|c|}{ Assays } \\
\hline & & & & $\begin{array}{l}\text { Dose } \\
\mathrm{mg} \cdot / 2 \mathrm{~kg} . \\
\text { body wt. }\end{array}$ & $\begin{array}{c}\text { Mean rate of } \\
\text { Ca-dec. } \% \\
(5 \text { rabbits })\end{array}$ \\
\hline 1 & 7.0 & $21 \sim 22$ & 1 & 3.0 & 8.54 \\
\hline 11 & 7.0 & 21 & 2 & 3.0 & 8.1 \\
\hline III & $7.0^{*}$ & $20 \sim 23$ & 17 & 3.0 & 4.59 \\
\hline \multicolumn{2}{|c|}{ Untreated } & & & 3.0 & 15.3 \\
\hline
\end{tabular}

* final pH 6.8-7.0.

activity they were eliminated or blocked by various reagents27). For example, the amine group was blocked or eliminated with ketene, nitrous acid, or fomaldehyde, and the phenyl radical in tyrosine was substituted with iodine by its application in neutral solution. As shown in Tables VIII X, these reagents either considerably diminished or destroyed the activity.

As for the -S-S- bond, a treatment for two days with forty volumes of cysteine at room temperature failed to change the activity, but a treatment for three days with twenty volumes of thioglycollic acid at room temperature diminished the activity by one-half (Table XI and XII).

From these findings it may be concluded that there is no special essential radical responsible for the appearance of the activity, as in the case of other proteo-hormones, and that the free amino radical, the tyrosine phenyl radical, and the $-\mathrm{S}-\mathrm{S}$ - bond are all responsible to the same degree for the activity.

Table XI. Effects of cysteine treatment on the parotin activity

\begin{tabular}{|c|c|c|c|c|c|c|}
\hline \multirow{3}{*}{ Experiments } & \multirow{3}{*}{$\begin{array}{l}\mathrm{pH} \text { of } \\
\text { solution }\end{array}$} & \multirow{3}{*}{$\begin{array}{l}\text { Temp. of } \\
\text { treatment } \\
{ }^{\circ} \mathrm{C}\end{array}$} & \multirow{3}{*}{$\begin{array}{l}\text { Time of } \\
\text { treatment } \\
\text { days }\end{array}$} & \multicolumn{3}{|c|}{ Assays } \\
\hline & & & & \multicolumn{2}{|r|}{ Dose } & \multirow[b]{2}{*}{$\begin{array}{c}\text { Mean rate of } \\
\text { Ca-dec. \% } \\
\text { (5 rabbits })\end{array}$} \\
\hline & & & & $\begin{array}{l}\text { Parotin } \\
\text { mg. } / 2 \mathrm{~kg} . \\
\text { body wt. }\end{array}$ & $\begin{array}{c}\text { As cysteine- } \mathrm{HCl} \\
\mathrm{mg} \cdot / 2 \mathrm{~kg} . \\
\text { body wt. }\end{array}$ & \\
\hline $\begin{array}{l}\text { Parotin }+40 \text { vols. } \\
\text { cystein }-\mathrm{HCl}\end{array}$ & 7.8 & $14 \sim 18$ & 2 & 3.0 & 120 & 11.84 \\
\hline $\begin{array}{l}\text { Control [1] parotin* } \\
40 \text { vols. cystein }-\mathrm{HCl}\end{array}$ & 7.8 & $14 \sim 18$ & 2 & 3.0 & 120 & 12.14 \\
\hline Confrol [II] cysteine & 8.0 & $14 \sim 18$ & 1 & 0.0 & 120 & 6.92 \\
\hline
\end{tabular}

* Solutions of parotin and cysteine were incubated and injected separately. 
Table XII. Effects of thioglycollic acid on the parotin activity

\begin{tabular}{cccccccc}
\hline \hline & & & & \multicolumn{3}{c}{ Assays } \\
\cline { 5 - 7 } Experiments & $\begin{array}{c}\mathrm{pH} \text { of } \\
\text { solution }\end{array}$ & $\begin{array}{c}\text { Temp. of } \\
\text { treat. } \\
{ }^{\circ} \mathrm{C}\end{array}$ & $\begin{array}{c}\text { Time of } \\
\text { treat. } \\
\text { days. }\end{array}$ & $\begin{array}{c}\text { Parotin } \\
\text { mg./2kg. }\end{array}$ & $\begin{array}{c}\text { Thiog. acid } \\
\text { mg. } / 2 \mathrm{~kg} . \\
\text { body wt. }\end{array}$ & $\begin{array}{c}\text { Mean rate of } \\
\text { Ca-dec. } \% \\
\text { (5 rabbits) }\end{array}$ \\
\hline $\begin{array}{c}\text { Parotin +thioglycollic } \\
\text { acid }\end{array}$ & 7.8 & $13 \sim 17$ & 3 & 4.0 & 80 & $9.64(4)^{*}$ \\
$\begin{array}{c}\text { Parotin thioglycollic } \\
\text { acid }^{* *}\end{array}$ & 7.8 & $13 \sim 17$ & 3 & 4.0 & 80 & $17.13(5)$ \\
\hline
\end{tabular}

( ) denotes number of rabbits used for the measurement.

* The heaviest rabbit among the five used in this experiment died, and some of others seemed to become convulsive after the intravenous injections of the solution, probably by the toxicity of thioglycollic acid.

** Solutions of parotin and thioglycollic acid were incubated and injected separately.

In order to see what change of activity will be brought by changing the form of the parotin molecule, the denaturation of parotin by urea and guanidine hydrochloride was examined 28 . As shown in Table XIII and XIV, the activity disappears once by the addition of urea but the activity reappeared after elimination of urea through dialysis and by standing for some time. In

Table XIII. Effect of urea on the parotin activity

\begin{tabular}{|c|c|c|c|c|c|c|}
\hline \multirow[b]{2}{*}{ Experiments } & \multirow{2}{*}{$\begin{array}{c}\text { Concentra- } \\
\text { tion of } \\
\text { urea } \\
M\end{array}$} & \multirow{2}{*}{$\begin{array}{c}\text { Time of } \\
\text { dialysis } \\
\text { day }\end{array}$} & \multirow{2}{*}{$\begin{array}{c}\text { Time passed } \\
\text { after } \\
\text { dialysis } \\
\text { day }\end{array}$} & \multicolumn{3}{|c|}{ Assays } \\
\hline & & & & $\begin{array}{c}\text { Date } \\
(1951)\end{array}$ & $\begin{array}{l}\text { Dose } \\
\mathrm{mg} \cdot / 2 \mathrm{~kg} \text {. } \\
\text { body wt. }\end{array}$ & $\begin{array}{c}\text { Mean rate of } \\
\text { Ca-dec. } \% \\
\text { (5 rabbits) }\end{array}$ \\
\hline Expt. I & 3.0 & 2 & 1 & III. 2 & 3.0 & $2.88^{\text {a) }}$ \\
\hline ditto* & 0 & & 15 & III. 16 & 3.0 & $12.40^{b)}$ \\
\hline Expt. II & 6.66 & 5 & 1 & III. 6 & 3.0 & $14.56^{\mathrm{c})}$ \\
\hline ditto & 0 & & 15 & III. 20 & 3.0 & 10.30 \\
\hline \multicolumn{3}{|c|}{ Untreated } & & II. 1 & 3.0 & 15.3 \\
\hline
\end{tabular}

* 14 days after assays were carried out, the solutions were saturated with toluene and preserved in a refrigerator.

a) The difference between 2.88 and 15.3 is significant. $(P=0.59)$

b) 2.88 " 12.40 " 12 " $(P=0.66)$

c) 1 2. $2.88 \% 14.56 \quad(P=0.1)$

Table XIV. Effect of guanidine hydrochloride on the parotin activity

\begin{tabular}{|c|c|c|c|c|c|c|}
\hline \multirow[b]{2}{*}{ Experiments } & \multirow{2}{*}{$\begin{array}{l}\text { Concentra- } \\
\text { tion of } \\
\text { guanidine- }\end{array}$} & \multirow[b]{2}{*}{$\begin{array}{l}\text { Time of } \\
\text { dialysis } \\
\text { day }\end{array}$} & \multirow{2}{*}{$\begin{array}{c}\text { Time pass- } \\
\text { ed after } \\
\text { dialysis } \\
\text { day }\end{array}$} & \multicolumn{3}{|c|}{ Assays } \\
\hline & & & & $\begin{array}{c}\text { Date } \\
(1951)\end{array}$ & $\begin{array}{l}\text { Dose } \\
\mathrm{mg} \cdot / 2 \mathrm{~kg} \text {. } \\
\text { body wt. }\end{array}$ & $\begin{array}{c}\text { Mean rate of } \\
\text { Ca-dec. \% } \\
\text { (5 rabbits) }\end{array}$ \\
\hline $\begin{array}{l}\text { Expt. [1] } \\
\text { ditto* } \\
\text { Expt. [II] } \\
\text { ditto** } \\
\text { Expt. [III] }\end{array}$ & $\begin{array}{l}6.0 \\
0 \\
6.0 \\
0 \\
6.0\end{array}$ & 3 & $\begin{array}{r}3 \\
15 \\
1 \\
13 \\
1\end{array}$ & $\begin{array}{l}\text { III. } 27 \\
\text { IV. } 9 \\
\text { IV. } 6 \\
\text { IV. } 13 \\
\text { IV. } 8\end{array}$ & $\begin{array}{l}3.0 \\
3.0 \\
3.0 \\
3.0 \\
6.0\end{array}$ & $\begin{array}{l}4.16 \# \\
3.49 \\
9.52 \# \\
6.05 \\
10.51 \#\end{array}$ \\
\hline \multicolumn{2}{|c|}{ Untreated } & & & II. 1 & 3.0 & 15.3 \\
\hline
\end{tabular}

* 13 days later since assays were carried out. The solutions were saturated with tolvene

** 12 days later since assays were carried out. $\}$ and preserved in a refrigerator.

\# Dialyses were carried out in a refrigerator. 
other words, parotin suffers reversible denaturation by urea similar to prolactin, the pituitary anterior hormone, while it urdergoes irreversible denaturation by guanidine.

\section{ISOLATION OF PAROTIN FROM THE HORSE PAROTID GLAND}

The crude and purified parotin were isolated from the horse parotid gland through the same process as that from cattle in order to compare the physical and chemical properties of the horse parotin with those of the cattle parotin in view of comparative endocrinology and to obtain more material resources of parotin ${ }^{29)}$. The parotid gland of the horse was chosen simply because of its easy availability. In this case also crude parotin precipitated at $\mathrm{pH} 5.4$, and the effective principle precipitated from $12.1 \%$ ammonium sulfate solution by ammonium sulfate fractionation. However, even three times repetition of precipitation from $12.1 \%$ ammonium sulfate solution did not produce crystalline precipitate but the spherical type. As shown in Table XV, the effect of this fraction per gram was $1 / 5$ of that of bovine parotin precipitate.

Table XV. Rabbit serum calcium level decreasing activity of the fraction; from horse and bovine parotid glands

\begin{tabular}{|c|c|c|c|c|}
\hline Samples & $\begin{array}{c}\text { Dose }{ }^{* *} \\
\mathrm{mg} \cdot / 2 \mathrm{~kg} . \\
\text { wt. }\end{array}$ & $\begin{array}{l}\text { No. of } \\
\text { rabbits } \\
\text { used }\end{array}$ & $\begin{array}{l}\text { Mean rate of } \\
\text { Ca-dec. } \%\end{array}$ & Remarks \\
\hline Horse pH 5.4-Precipitate & $\begin{array}{l}40 \\
30\end{array}$ & $\begin{array}{l}3 \\
3\end{array}$ & $\begin{array}{l}13.9 \\
9.53\end{array}$ & $\left.\begin{array}{l}30 \mathrm{mg} . / \mathrm{cc} . \\
18.68 \mathrm{mg} . / \mathrm{cc} .\end{array}\right\} \begin{array}{l}\text { Physiol. } \\
\text { saline soln. }\end{array}$ \\
\hline Bovine $\mathrm{pH}$ 5.4-Precipitate & 10 & 5 & 8.26 & $2 \%$ aq. solution \\
\hline $\begin{array}{l}\text { Horse } 12 \%-\left(\mathrm{NH}_{4}\right)_{2} \mathrm{SO}_{4}{ }^{*}- \\
\text { fraction }\end{array}$ & $\begin{array}{l}5 \\
2.5\end{array}$ & $\begin{array}{l}3 \\
3\end{array}$ & $\begin{array}{l}13.9 \\
6.48\end{array}$ & Dialyzate $7.35 \mathrm{mg} . / \mathrm{cc}$. \\
\hline $\begin{array}{l}\text { Bovine } 12.1 \%-\left(\mathrm{NH}_{4}\right)_{2} \mathrm{SO}_{4} \\
\text { fraction }\end{array}$ & 1 & 5 & 14.41 & Dialyzate of crysta!s. $0.2 \%$ \\
\hline $\begin{array}{l}\text { Horse }\left(\mathrm{NH}_{4}\right)_{2} \mathrm{SO}_{4} \text {-Saturated } \\
\text { fraction }\end{array}$ & $\begin{array}{r}10 \\
5\end{array}$ & $\begin{array}{l}3 \\
3\end{array}$ & $\begin{array}{l}13.9 \\
9.44\end{array}$ & Dialyzate $9.562 \mathrm{mg} . / \mathrm{cc}$. \\
\hline $\begin{array}{l}\text { Bovine }\left(\mathrm{NH}_{4}\right)_{2} \mathrm{SO}_{4} \text {-Saturated } \\
\text { fraction }\end{array}$ & 2 & 6 & 7.11 & Dialyzate $0.222 \%$ \\
\hline
\end{tabular}

* weight percentage. $* *$ intravenous injectian.

Both parotins were compared in Fig. 21 which shows electrophoretic patterns of $\mathrm{pH} 5.4$ precipitate, ammonium sulfate $12 \%$ precipitate, and ammonium sulfate saturation precipitate of horse and bovine parotin, respectively. The effective bovine parotin precipitate from 12\% ammonium sultate solution showed mobility between $\alpha$-globulin and albumin of human serum and the mobility was rather similar to that of albumin, while horse parotin $12 \%$ ammonium sulfate precipitate showed greater mobility than human serum albumin ${ }^{29)}$. 
a. $\mathrm{pH}$ 5.4-precipitate fraction

Bovine

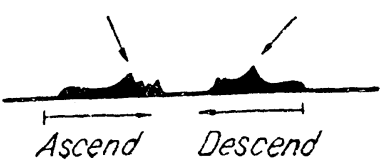

$\mathrm{pH} 8.0,0.05 \mathrm{M}$ phosphate buffer. $4-5 \mathrm{v} / \mathrm{cm}$., $42 \mathrm{~min} ., 18^{\circ} \mathrm{C}$.

Insoluble matter was filtered off through an asbestos filter plate. Arrows show the peak of the effective component.

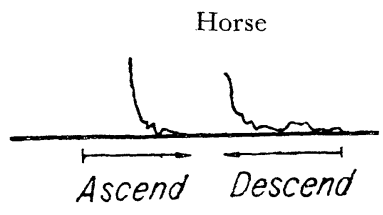

$\mathrm{pH} 7.9,0.05 \mathrm{M}$ phosphate buffer. $18 \mathrm{mAmp}$, $75 \mathrm{~min} ., 10^{\circ} \mathrm{C}$.

The peak of an effective component is indistinct, owing to the light passage being disturbed by an insoluble matter.

b. $12 \%\left(\mathrm{NH}_{4}\right)_{2} \mathrm{SO}_{4}$-precipitate fraction

Bovine

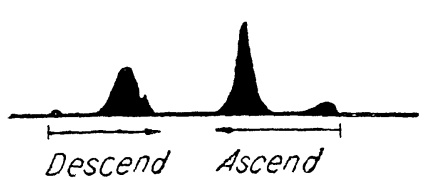

pH 7.9, $0.05 \mathrm{M}$ phosphate buffer. $4-5 \mathrm{v} / \mathrm{cm} ., 61 \mathrm{~min} ., 17.9^{\circ} \mathrm{C}$.

Mobility of the effective component lies intermediately between that of albumin and $a$-globulin of human serum, and much nearer that of $a$-globulin. Purity: ca. 90\%.

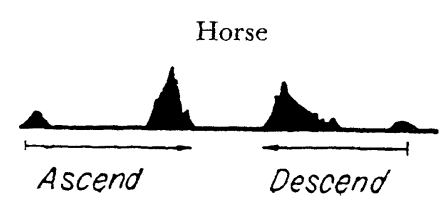

$\mathrm{pH} 7.9,0.05 \mathrm{M}$ phosphate buffer. $18 \mathrm{mAmp}$, $65 \mathrm{~min} ., 26^{\circ} \mathrm{C}$.

Effective component shows a greater mobility than that of human serum albumin. Patterns appear to be complicated.

$$
\text { c. Saturated }\left(\mathrm{NH}_{4}\right)_{2} \mathrm{SO}_{4} \text {-precipitate fraction }
$$

Bovine

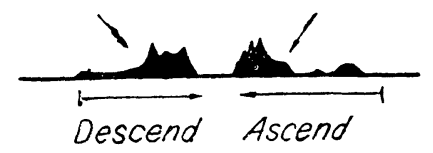

$\mathrm{pH} 8.0,0.05 \mathrm{M}$ phosphate buffer. $4-5 \mathrm{v} / \mathrm{cm}$., $45 \mathrm{~min} ., 18^{\circ} \mathrm{C}$.

It seerns to be composed of a mixture of several kinds of components and a small amount of effective component is present at the point shown by arrows but the majority of patterns shows greater mobility than the effective component.

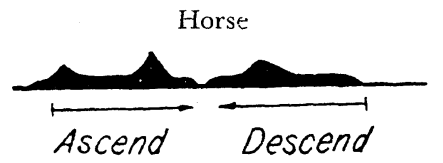

$\mathrm{pH} 7.9,0.05 \mathrm{M}$ phosphate buffer. 24.5 mAmp., 49 min., $10^{\circ} \mathrm{C}$.

Although it appears to be a simple pattern, the mobility of patterns is greatly dispersed.

Fig. 21. Electrophoretic patterns of fractions from bovine and horse parotic glands.

\section{PAROTIN IN HUMAN SALIVA (SALIVA-PAROTIN)}

Dr. Ogata had long ago discovered that human saliva contains a salivary gland hormone activity by injecting it into animals. This view was also confirmed by Granados ${ }^{30}$ ) who noticed that administration of human saliva mixed with feed promoted the growth of infant hamsters. He considered that the growth-promot- 
ing factor in saliva was not vitamin B but must have been other vitamin factors or some hormones.

The author and others ${ }^{31)}$ tested the rabbit serum calcium reduction effect, the rat incisor growth-promoting effect (Dr. Ishii $\left.{ }^{4}\right)$ took charge of this effect), and amylase activity of the following fractions:

A) The precipitate yielded by adding to the human saliva the same volume of ethanol as that of the saliva and a half volume of ether.

Table XVI.

\begin{tabular}{|c|c|c|c|c|c|}
\hline Sample & Yield $(\%)$ & $\begin{array}{c}\text { Dase } \\
\mathrm{mg} . / 2 \mathrm{~kg} . \\
\text { (Subcutaneous) }\end{array}$ & $\begin{array}{c}\text { Mean rate of } \\
\text { Ca-dec. } \% \\
\text { (3 rabbits) }\end{array}$ & $\begin{array}{c}\text { Effect on } \\
\text { growth } \\
\text { of } \\
\text { incisor }\end{array}$ & $\begin{array}{c}\text { Amylase } \\
\text { effect }\end{array}$ \\
\hline Precipitate A & 0.13 & 7.5 & 15.4 & $+H$ & strong \\
\hline Precipitate B & 0.01 & 0.6 & 13.1 & $t+?$ & very weak \\
\hline Motherliquid $\mathrm{C}$ & 35.0 & 59 & 9.8 & + & \\
\hline
\end{tabular}

Table XVII. The isolaiion of "Saliva-parotin" from human Saliva

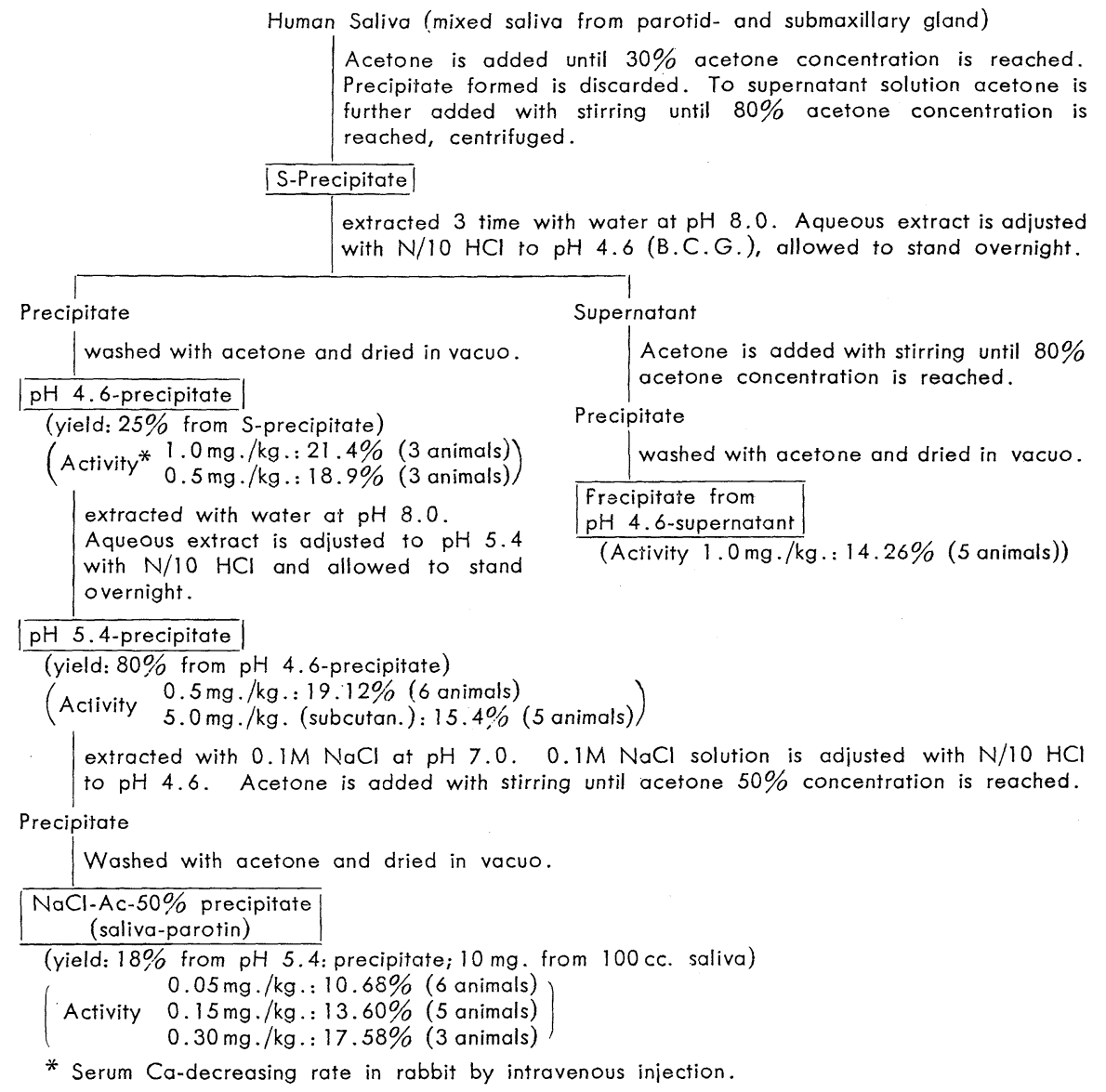


B) The small amount of precipitate yielded by the addition of a half volume of ether to the supernatant of (A).

C) Concentrated supernatant of (B).

The results, as shown in Table XVI, indicated that (B) possessed the largest calcium reduction effect, followed by $(\mathrm{A})$ and $(\mathrm{C})$.

(A) possessed the largest amylase effect which was very weak in (B). Human

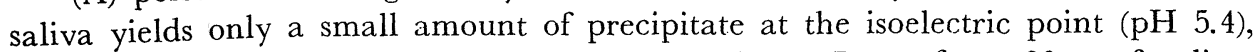
but a very small amount of very active precipitate $(7 \mathrm{mg}$. from $90 \mathrm{~g}$. of saliva, $0.6 \mathrm{mg}$. of which corresponds to 1 unit) was produced by saturation of $\mathrm{NaCl}$ at $\mathrm{pH}$ 5.4. The mother liquid, dialized to remove the salt followed by saturation with ammonium sulfate, gave precipitate but the activity was equally distributed in the precipitate and the mother liquid (The activity per gram of both precipitate and the supernatant was $1 / 5$ of the precipitate from $\mathrm{NaCl}$ saturated solution of $\mathrm{pH}$ 5.4), this process, therefore, could not be used as a purification method ${ }^{32}$.

Very recently, the author and his associate ${ }^{33)}$ have succeeded to isolate very potent fraction ('saliva-parotin') from human saliva with the procedure as shown in Table XVII. This preparation is in rabbit serum Ca-decreasing assay about 7 times as active as parotin.

Furthermore, we have shown that the active principle in human saliva was contained in non-amylase fraction and not in amylase fraction with Meyer's procedure ${ }^{35)}$ obtaining crystalline amylase from human saliva ${ }^{34)}$.

\section{SOME PROPERTIES OF 'SALIVA-PAROTIN' 33)}

The potent 'saliva-parotin' (the 'NaCl-Ac-50\%-precipitate' fraction in Table. XVII) is a white powder and dissolves completely in alkaline water and precipitates out at $\mathrm{pH} 3.4$ (with glass-electrode). It contains 9.8\% Nitrogen and has 72.7\% purity by electrophoretic analysis (Fig. 22). The polarogram of this

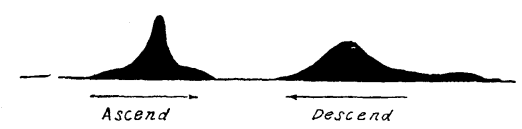

pH 9.78, $0.2 \mathrm{M}$ borate buffer, $15^{\circ} \mathrm{C}, 30 \mathrm{~min} ., 7.0 \mathrm{mAmp}$, purity: $72.7 \%$ (by ascending).

Fig. 22. Electrophoretic patterns of saliva-parotin preparation.

preparation under the same conditions as those of parotin shows 3 waves just as that of parotin and the half wave potential of the second wave, of which we consider to be characteristic for parotin protein, is -1.36 Volt (in the case of parotin this value is -1.35 Volt).

It shows the all color reactions of proteins, e.g., biuret, xanthoproteic, ninhydrin, Folin's, Molisch's, Pauli's and Sakaguchi's reactions, but only the Millon's reaction is not distinct. It does not coagulate in aqueous solution by heating, but precipitates with picric acid, trichloroacetic acid, phosphotungstic acid, meta phosphoric acid, sulfosalicylic acid, lead acetate and sublimate solutions.

This preparation shows much more potent biological reactions not only in the rabbit serum calcium decreasing activity, but also in the increasing activity 
of the number of circulating leucocytes in the rabbit blood (Fig. 23), in the elevating activity of the rabbit bone marrow temperature and also in the histological calcium depositing activity of rabbit incisors assayed by the 'Okada-Mimura's time marking method by lead acetate vital staining' than the parotin does33). Various studies are now being made concerning human saliva.

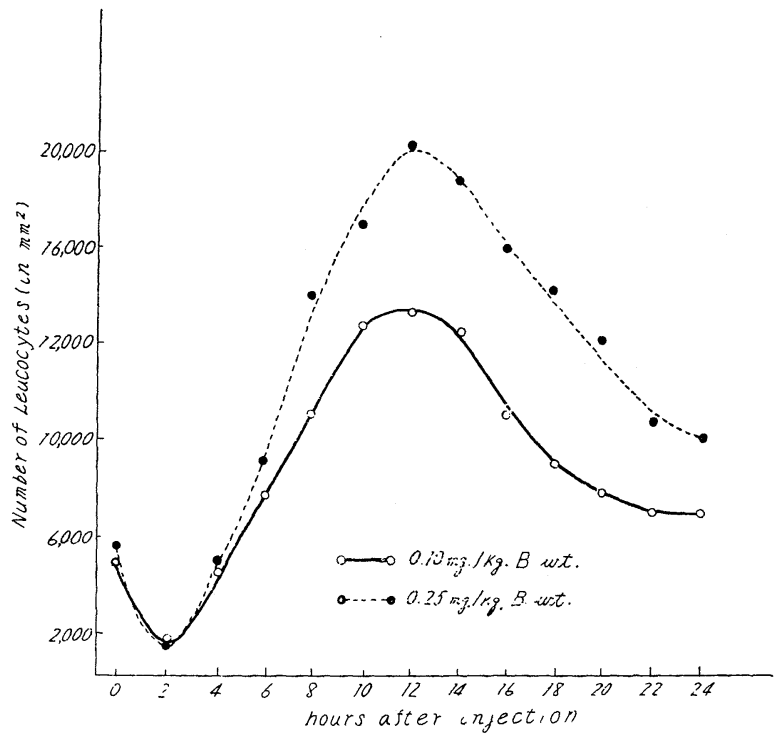

Fig. 23. Effect of saliva-parotin on the circulating leucocytes counts in rabbits.

\section{PAROTIN-LIKE SUBSTANCE (URO-PAROTIN) IN HUMAN URINE}

It has long been a mystery of the filtration function of kidney glomerulus that gonadotropin in pregnant mare serum, whose molecular weight is assumed to be about 30,000 , is not excreted into the urine, while human chorionic gonadotropin, whose molecular weight is about 100,000 , is excreted to the urine of pregnant woman. Although the essential character of human parotin has not been elucidated as yet, judging trom the size of the bovine parotin molecule, it must be of considerable size. Therefore, it would be hard to think that parotin will be excreted into urine without change. However, it might be possible to assume that parotin, after being metabolized into a rather smaller molecule which still retains the specific activity, would be valid the presence of parotin-like substances in human urine. On this assumption, examination of the principle in question in healthy young men was attempted. As a result, the precipitate trom benzoic acid adsorption and acetone precipitate were found to have strong serum calcium reducing activity (Table XVIII a, b, and c; Table XIX).

These precipitates were further purified by ammonium sulfate fractionation in the same manner as that for the bovine parotin. The activity per gram of 
Table XVIIla. Isolation of crude uro-parotin from young men's urine by the acetone method

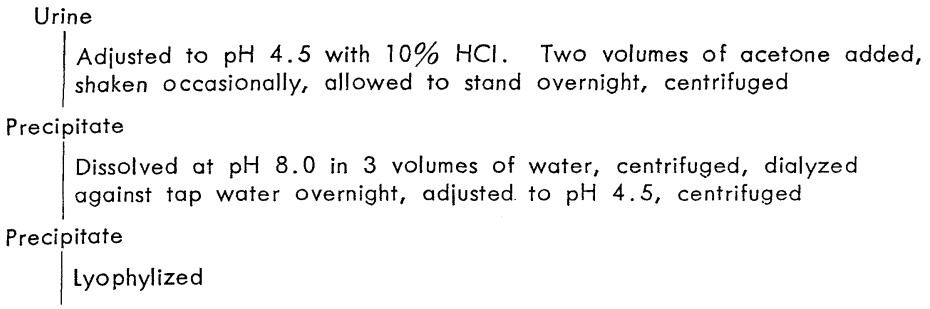
Lyophylized powder

Table XVIIIb. Isolation of crude uro-parotin from young men's urine by the benzoic acid method

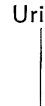

Adjusted to $\mathrm{pH} 4.0$ with glacial acetic acid. $50 \mathrm{cc}$. acetone solution saturated with benzoic acid added dropwise per liter urine

Precipitate

Extracted with acetone, centrifuged

Acetone-insoluble residue

Washed with acetone, extracted with water at $\mathrm{pH} 8.0$.

Aqueous solution dialyzed against tap water overnight.

Dialyzate adjusted to $\mathrm{pH} \mathrm{4.5,} \mathrm{centrifuged}$

Precipitate

Lyophylized

Lyophylized powder

Table XVIIIc. Isolation of crude uro-parotin from young men's urine by the dialysis-concentration method

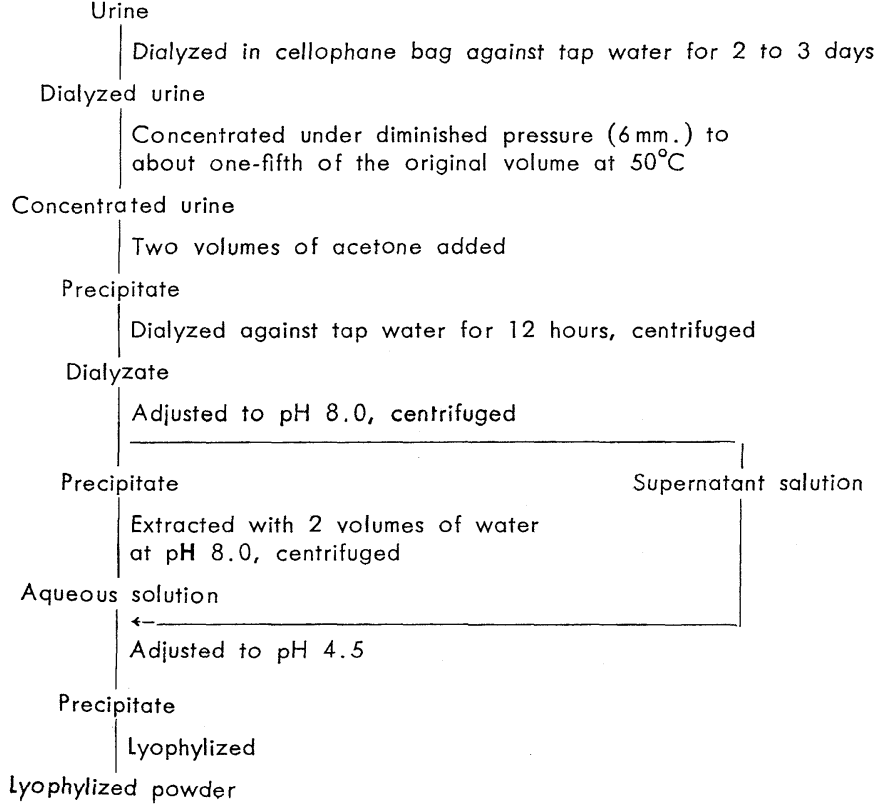

Lyophylized powder 
Table XIX. Yields and rabbit serum Ca-decreasing activities of crude and purified uro-parotins

\begin{tabular}{llcc}
\hline \hline $\begin{array}{c}\text { Methods obtaining } \\
\text { crude uro-parotin }\end{array}$ & Preparation & $\begin{array}{c}\text { Yield mg./L. } \\
\text { urine }\end{array}$ & $\begin{array}{c}\text { The serum } \\
\text { decreasing } \% \%^{*} \\
\text { (average of 4 rabbits) }\end{array}$ \\
\hline Acetone method & Crude & 45.7 & -8.91 \\
Benzoic acid method & Purified & 9.5 & -16.63 \\
Dialysis-concentration method & Crude & 36.4 & -12.26 \\
& Purified & 4.6 & -22.48 \\
& Crude & 69.5 & -15.02 \\
\hline
\end{tabular}

* Doses: $2.5 \mathrm{mg}$. per rabbit body weight, intravenously.

the ammonium sulfate $12.5 \%$ precipitate was twice as much as that of unpurified crude material, and the purity of the precipitate was found to be $82.4 \%$ by electrophoresis (see Fig. 24) ${ }^{36}$ ). As shown in Fig. 25, the ultraviolet spectrum of

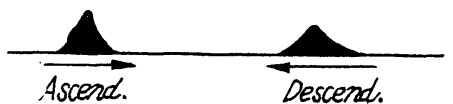

$1 \%$ Solution, $\mathrm{pH} 8.0,0.05 \mathrm{M}$ phosphate buffer, $13^{\circ} \mathrm{C}, 98 \mathrm{Volt}, 9 \mathrm{~mA} .90$ minutes, purity: $82.4 \%$ (by ascending).

Fig. 24. Electrophoretic pattern of the purified uro-parotin

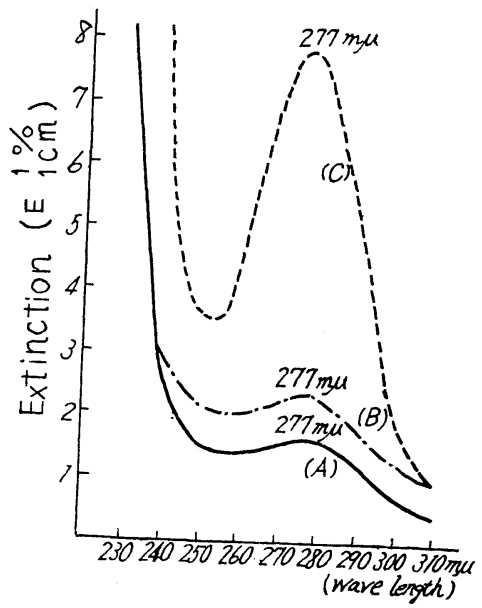

A: Crude parotin ( $\mathrm{pH}$ 5.4-precipitate), purity: $68.0 \%$

B: Purified uro-parotin, purity: $82.4 \%$

C: Purified parotin, purity: 96.4\%

Fig. 25. Absorption spectra of purified uro-parotin, crude and purified parotin.

the precipitate showed its maxımum absorption at the same wave length, $277 \mathrm{~m} \mu$ as that of parotin, but the $E_{1 \mathrm{~cm}}^{1 \%}$ value was rather small and close to that of crude parotin.

Table XX shows the halt-wave potentials of polarogram of purified uro-parotin under the same conditions as those of parotin. The half-wave potentials of the second wave of uro-parotin is the same as that of parotin, and that of the third wave is very close to that of parotin.

Purified uro-parotin gives positive biuret, xanthoproteic, Millon's, AdamKiewitz's, and Sakaguchi's reactions, but negative ninhydrin reaction. It gives precipitation by addition of acid or alcohol but is not coagulated by heating. 
Table XX. Pclarographic half wave potentials of uro-parotin and parotin

\begin{tabular}{|c|c|c|c|c|}
\hline \multirow{3}{*}{ Preparations } & \multicolumn{4}{|c|}{$E^{1 / 2}$ (S.C.E.) } \\
\hline & \multicolumn{2}{|c|}{$\mathrm{Co}^{++}$-electrolyte } & \multicolumn{2}{|c|}{$\mathrm{Co}^{+++}$-electrolyte } \\
\hline & 2nd. wave & 3rd. wave & 2nd. wave & 3rd. wave \\
\hline $\begin{array}{l}\text { Uro-parotin No. } 22^{*} \\
\text { Uro-parotin No. } 31^{* *} \\
\text { Parotin, purified }\end{array}$ & $\begin{array}{l}-1.35 \text { Volt } \\
-1.35 \text { Volt }\end{array}$ & $\begin{array}{l}-1.56 \text { Volt } \\
-1.57 \text { Volt }\end{array}$ & $\begin{array}{l}-1.35 \text { Volt } \\
-1.35 \text { Volt } \\
-1.35 \text { Volt }\end{array}$ & $\begin{array}{l}-1.56 \text { Volt } \\
-1.56 \text { Volt } \\
-1.60 \text { Volt }\end{array}$ \\
\hline
\end{tabular}

* Crude preparation was prepared by the benzoic acid method and then purified.

** Crude preparation was prepared by the acetone method and then purified.

It is precipitated by heavy metal salts, phosphotungstic acid, sulfosalicylic acid, and picric acid, and gives positive Molisch's reaction ${ }^{36)}$.

The effect of purified uro-parotin on the number of circulating leucocytes, as shown in Fig. 26 was exactly the same as that of parotin ${ }^{36)}$. The experimental

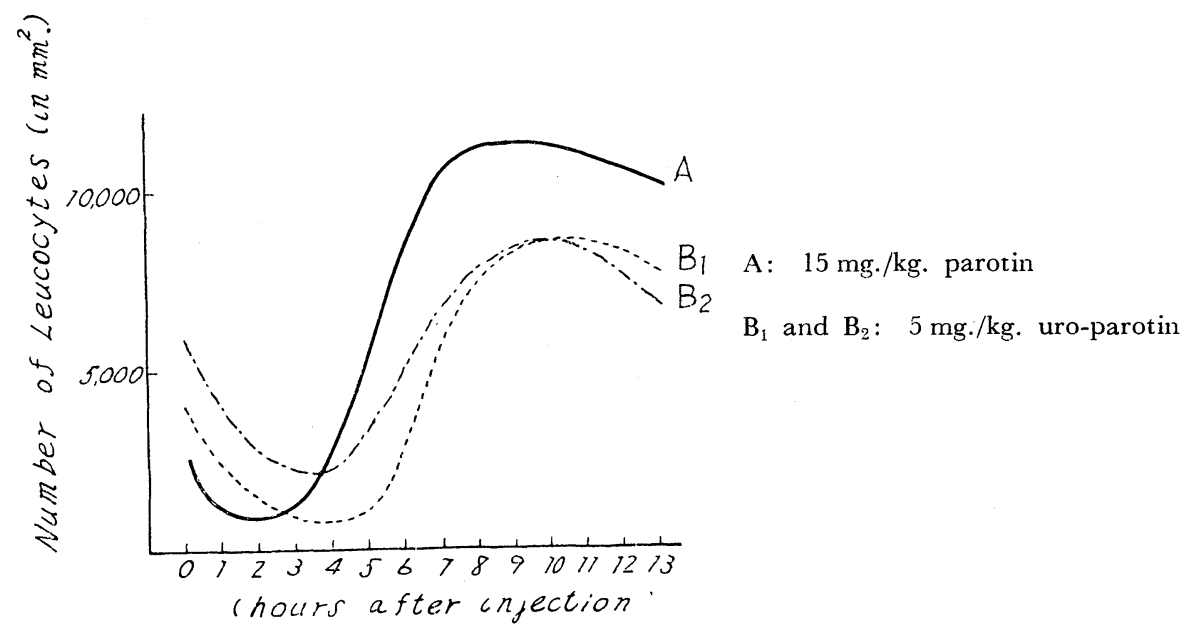

Fig. 26. The effect of purified uro-parotin on the circulating leucocyte counts in rabbits.

result of Dr. Huse and Mr. Matsuda (Gunma University) show that the uroparotin promotes the calcification of rabbit incisor dentin in the same manner as parotin. No change of blood pressure was observed on the intravenous injection of $10 \mathrm{mg} . / \mathrm{kg}$. of purified uro-parotin in a urethane anesthetized cat ${ }^{36}$. Studies are now being made on this substance.

\section{PAROTIN-LIKE SUBSTANGE IN THE BOVINE SUBMAXIL- LARY GLAND (S-PAROTIN)}

According to the salivary gland endocrine theory, the principal role of the endocrine process is played by the parotid gland, and the submaxillary gland merely cooperates with it. Therefore, must be an active substance in the submaxillary gland having the same effect as that of parotin which might be identical to parotin. The author and his associates have been engaged in such a study 
and recently succeeded in isolating a parotin-like substance (s-parotin) trom the bovine and horse submaxillary gland. This purified s-parotion is considered not only to have physiological and chemical interest but also to be one of the proofs of the salivary gland endocrine theory.

The author and his associate ${ }^{54)}$ found previously that crude parotin decreased the rabbit serum calcium level and increased the inorganic phosphorus in serum (cf. II: "Effect on Inorganic Substances in Blood" in the chapter of "Biological Actions of Parotin"), and that the purification inversed the action on the serum inorganic phosphorus 37 .

In other words, parotin by purification causes a decrease of serum calcium content. Contrary to parotin, a physiological saline extract of the submaxillary gland of rabbit and cattle remarkably decreased the amount of serum inorganic phosphorus, but does not effect the amount of serum calcium ${ }^{37}$ ).

Then, the bovine submaxillary glands went through the same process as that of crude parotin isolation from the parotid gland ${ }^{38)}$. The precipitate obtained at the isoelectric point of $\mathrm{pH} 4.5$ remarkably decreased the serum phosphorus content, as the physiological saline extract did. Contrary to this, the same precipitate did not affect the serum calcium content ${ }^{38)}$. The serum inorganic phosphorus reduction activity of this crude preparation was sensitive to heat, acid and especially heating in acidic solution ${ }^{38)}$. Mr. N. Matsuda ${ }^{39)}$ (Gunma University) using the "Okada-Mimura's time marking method by lead acetate vital staining", proved that this fraction possessed the same promotive effect on calcification of rabbit incisor dentin as that of parotin.

This $\mathrm{pH}$ 4.5-precipitate was fractionated with ammonium sulfate in just the same way as parotin and dialyzed ${ }^{38)}$. The strong serum inorganic phosphorus reduction was found in the precipitate from 12.5\% ammonium sulfate (hereafter this activity will be called P-effect and the substance having P-effect will be called P-substance). However, only a slight rise of serum calcium reducing activity was seen and not the remarkable increase of this activity by such a purification process in the case of parotin (from here on this calcium reducing activity will be called Ca-effect and the substance having this effect will be called Ca-substance). As shown in Fig. 27 and 28 the pH 4.5-precipitate was 25\%

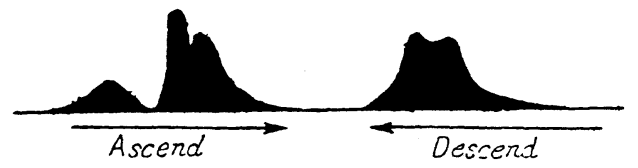

$\mathrm{pH}$ 8.0, $0.05 \mathrm{M}$ phosphate buffer, $15^{\circ} \mathrm{C}, 30 \mathrm{~min} ., 110 \mathrm{~V}$, $9 \mathrm{~mA}$. Purity: ca. $25 \%$.

Fig. 27. Electrophoretic pattern of $\mathrm{pH}$ 4.5-precipitate.

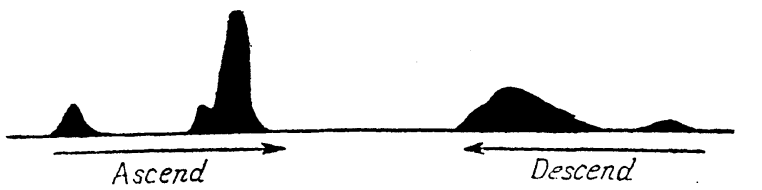

$\mathrm{pH} 8.0,0.05 \mathrm{M}$ phosphate buffer, $21^{\circ} \mathrm{C}, \quad 30 \mathrm{~min} ., \quad 119 \mathrm{~V}, \quad 9 \mathrm{~mA}$. Purity: ca. $80 \%$.

Fig. 28. Electrophoretic pattern of $\left(\mathrm{NH}_{4}\right)_{2} \mathrm{SO}_{4}-12.5 \%$ traction. 
before treatment but purification through this process gave $80 \%$ purity in the $12.5 \%$ ammonium sulfate precipitate ${ }^{40)}$.

This precipitate from $12.5 \%$ ammonium sulfate solution having a strong $\mathrm{P}$ effect and a weak Ca-effect was fractionated by $\mathrm{Na}_{2} \mathrm{SO}_{4}{ }^{40)}$. A strong Ca-effect was found in the dialyzates of this $12.5 \%$ ammonium sulfate precipitate or in the precipitate trom $15.4 \% \mathrm{Na}_{2} \mathrm{SO}_{4}$ solution ${ }^{40)}$. Each precipitate of the ammonium sulfate fractionation process was dialyzed in a celophane bag against running water for one night and precipitated by adjusting the $\mathrm{pH}$ to 4.5 . The Ca-effect of all these precipitates was increased by this process, and the increase of the effect of the precipitates from $12.5 \%$ and $24 \%$ ammonium sulfate solution was most remarkable, but the P-effect was decreased ${ }^{40)}$. The result of this experiment showed that $\mathrm{Na}_{2} \mathrm{SO}_{4}$ fractionation or dialysis revealed clearly the latent $\mathrm{Ca}$ activity. It was confirmed by the Wohlgemuth's method that $12.5 \%$ ammonium sulfate precipitate possessed no amylase activity ${ }^{40)}$.

The separation of the P-substance and the Ca-substance was effected successfully by the counter-current distribution method and fractionation with alcohol at a low temperature ${ }^{41}$.

The experiment was carried out as follows: With 30 counter-current tubes being used, the $\mathrm{pH} 4.5$ precipitate was distributed between a phosphate buffer of $\mathrm{pH} 8.0$ and chloroform. As shown in Fig. 29, the precipitate having a strong

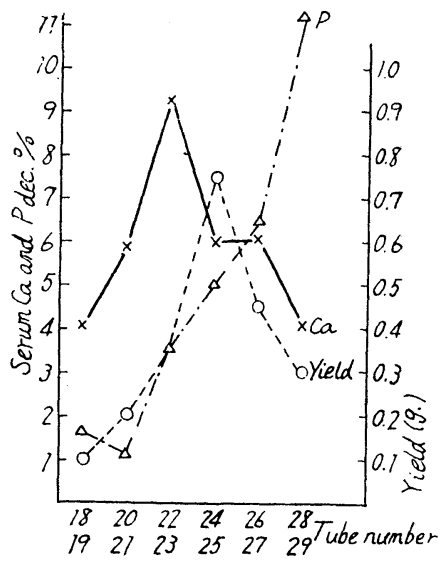

Fig. 29. Thirty-transfer-distribution of $\mathrm{pH} 4.5$-precipitate.

Ca-effect and weak P-effect was found mainly in the 22nd and the 23rd tubes. On the other hand, the precipitate having a strong P-effect and a weak Ca-effect was found in the 28th and 29th tube.

In alcoholic fractionation, the $\mathrm{pH}$ 4.5-precipitate and the precipitate from $12.5 \%$ ammonium sulfate solutions were each divided with cooling into two parts, namely, the part which was precipitated by makıng the solution to $60 \%$ alcohol solution and the other which was precipitated by making the solution from 60 to $80 \%$ alcohol solution. Strong Ca-effect was tound in the precipitate from the $80 \%$ alcohol solution and almost no Ca-effect was found in the precipitate from 
the $60 \%$ solution. On the contrary, the weaker P-effect was found in the precipitate from both the $60 \%$ and $80 \%$ solutions. Judging from these facts it was considered that the P-effect was sensitive to alcohol even at low temperatures but the Ca-effect was not sensitive. The aqueous solution ( $\mathrm{pH} \mathrm{8.0)}$ of the precipitate from the $80 \%$ alcohol solution showed an ultraviolet absorption maximum at $276.5 \mathrm{~m} \mu$ as shown in Fig. 30 and Table XXI, which agrees with that of parotin at $277 \pm 0.5 \mathrm{~m} \mu$.

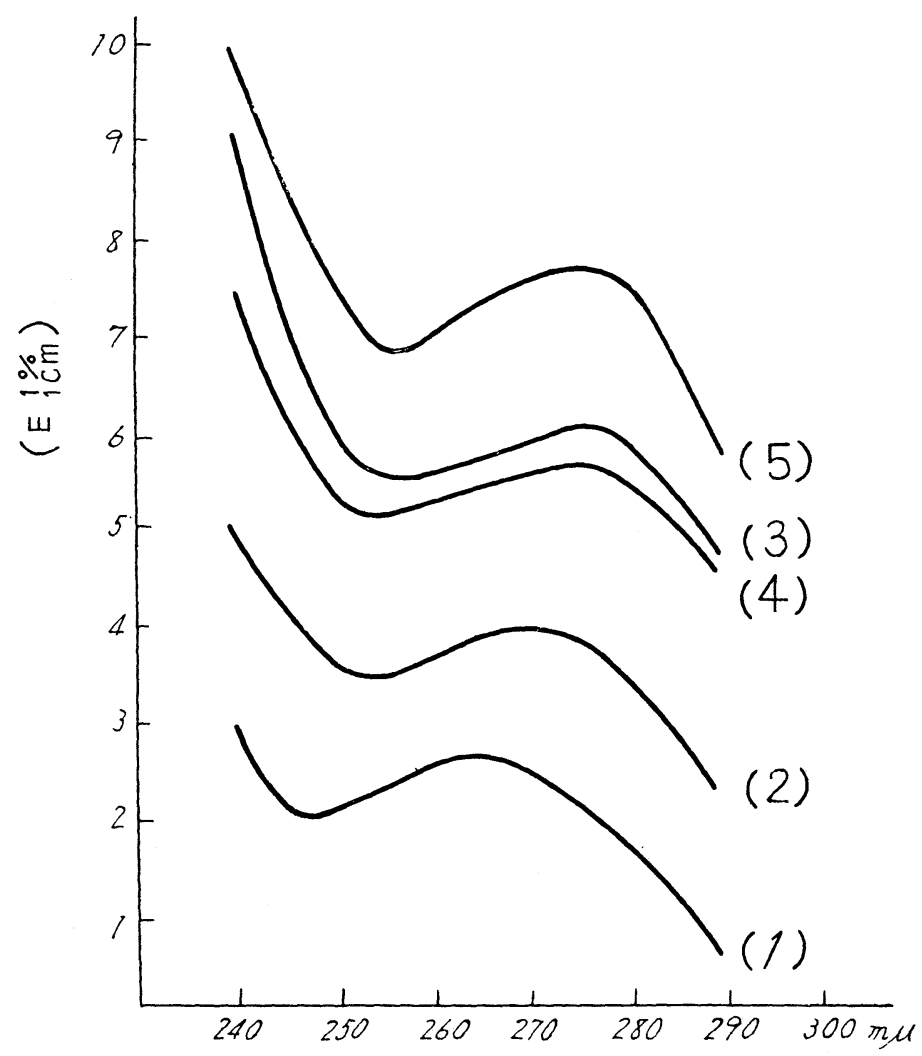

(1) $\mathrm{pH} 4$ 4.5-precipitate; (2) Ammonium sulfate $12.5 \%$-precipitate; (3) Ammonium sulfate $12.5 \%$-precipitate (dialyzed); (4) Alcohol $80 \%$-precipitate and (5) S-parotin.

Fig. 30. Ultraviolet absorption spectra of bovine submaxillary gland extracts in various purity

This $80 \%$ alcohol-precipitate was dissolved in water at $\mathrm{pH} 8.0$ and passed through alumina column $(25 \mathrm{~cm} . \times 1.2 \mathrm{~cm}$.). The filtrate was dialyzed against tap water and saturated ammonium sulfate solution was added to the dialyzate until the concentration of ammonium sulfate reached to $12.5 \%$. The precipitate was collected by centrifugation and again dialyzed against tap water. The dialyzate was adjusted to $\mathrm{pH} 4.5$ and the precipitate was dissolved in water at $\mathrm{pH} 8.0$ and 
Table XXI. Ultraviolet absorption maxima of bovine submaxillary gland extracts in various purity

\begin{tabular}{|c|c|c|}
\hline Fraction & Buffer $(\mathrm{pH})$ & $\begin{array}{c}\operatorname{maximum}(\mathrm{m} \mu) \\
\text { Absorption }\end{array}$ \\
\hline $\begin{array}{l}\mathrm{pH} 4.5 \text {-precipitate } \\
\left(\mathrm{NH}_{4}\right)_{2} \mathrm{SO}_{4} 12.5 \% \text {-precipitate } \\
\left(\mathrm{NH}_{4}\right)_{2} \mathrm{SO}_{4} 12.5 \% \text {-precipitate (dialyzed) } \\
\text { Alcohol } 80 \% \% \text {-precipitate } \\
\text { S-parotin } \\
\text { Parotin }\end{array}$ & $\begin{array}{c}0.05 \mathrm{M} \text { Phosphate }(\mathrm{pH} 8.0) \\
" \prime \prime \\
" 1 \\
\text { Veronal (pH } 8.8) \\
0.05 \mathrm{M} \text { Phosphate }(\mathrm{pH} 8.0)\end{array}$ & $\begin{array}{l}265 \\
268 \\
276.8 \\
276.5 \\
276.5 \pm 0.5 \\
276.5 \pm 0.5\end{array}$ \\
\hline
\end{tabular}

then passed through Amberlite IR4B column $(25 \mathrm{~cm} \times 1.2 \mathrm{~cm})$. The filtrate was adjusted to $\mathrm{pH} 4.5$ and the precipitate was dissolved in water at $\mathrm{pH} 8.0$ and again the aqueous solution was adjusted to $\mathrm{pH} 4.5$ and the precipitate was lyophylized. This preparation (S-parotin) had the serum calcium reducing activity of $24.5 \%$, the serum inorganic phosphorus reducing activity of $6.4 \%$ (average value of 6 rabbits) with intravenous injection of $1 \mathrm{mg} . / \mathrm{kg}$., respectively and the purity of $93.8 \%$ (Fig. 31) $)^{42)}$.

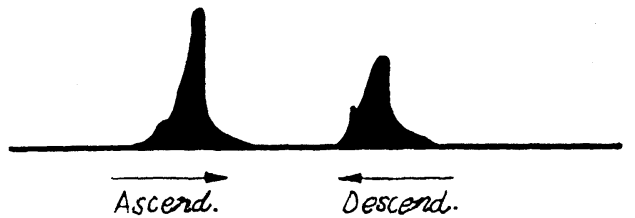

pH 8.0, veronal buffer, 6 mAmp., 45 min., $15^{\circ} \mathrm{C}$. purity: $93.8 \%$ by ascending.

Fig. 31. Electrophoretic pattern of S-parotin.

It is of interest that in proportion to the increase of the Ca-effect of the protein, the wave length at which maximum absorption occurrs approaches that of parotin and finally both became identical, as evidenced by the in Table XXI presented data of absorption maximum (see also Fig. 3042). This fact suggests that the maximum absorption at $277 \pm 0.5 \mathrm{~m} \mu$ is specific to parotin and that the submaxillary gland contains a parotin-like substance. Table XXII gives the halfwave potentials of polarogram of the precipitate from the $80 \%$ alcohol solution and of S-parotin drawn under the same formerly described condition as those of parotin.

Table XXII. Polarographic half wave potentials of $80 \%$ alcohol precipitatate and S-parotin

\begin{tabular}{|c|c|c|c|c|}
\hline \multirow{2}{*}{$\frac{\text { Half wave potential }}{\text { Electrolyte }}$} & \multicolumn{4}{|c|}{$E^{1 / 2}$ (S.C.E.) } \\
\hline & \multicolumn{2}{|c|}{$\mathrm{Co}^{++}$} & \multicolumn{2}{|c|}{$\mathrm{Co}^{+++}$} \\
\hline Sample Wave No. & 2nd. & $3 r d$. & 2 nd. & $3 r d$ \\
\hline $\begin{array}{l}80 \% \text { Alcohol-precipiřate } \\
\text { S-parotin } \\
\text { Parotin }\end{array}$ & $\begin{array}{r}V \\
-1.34 \\
-1.33 \\
-1.35\end{array}$ & $\begin{array}{r}\mathrm{V} \\
-1.60 \\
-1.57\end{array}$ & $\begin{array}{r}V \\
-1.34 \\
-1.35 \\
-1.35\end{array}$ & $\begin{array}{r}V \\
-1.54 \\
-1.58 \\
-1.60\end{array}$ \\
\hline
\end{tabular}

The paper chromatogram (using No. 50 Toyo Roshi filter paper, two dimensional ascending method, and ninhydrin as coloring agent) of S-parotin (96.1\% purity)-hydrolyzate with $\mathrm{HCl}$ (using solvent mixture of $\mathrm{n}$-butanol-acetic acid- 
water (4:1:2) and 20\% aq. phenol as developing agents) and baryta (using nbutanol saturated with water and solvent mixture of n-butanol - acetic acid - water (4:1:2) as developing agents) revealed as shown in Fig. 32 and 33 that the Sparotin contained the following 16 amino acids: leucine, methionine, threonine, phenylalanine, tyrosine, alanine, lysine, glycine, serine, glutamic acid, cystine, aspartic acid, proline, arginine, histidine, and tryptophan ${ }^{43)}$.

The result of elementary analysis of S-parotin gave the following values: carbon: $49.53 \%$; hydrogen: $7.35 \%$ and nitrogen: $14.05 \%$.

The effect of each precipitate from the submaxillary gland extract on the number of circulating leucocytes was observed. An intravenous injection of $5 \mathrm{mg} . / \mathrm{kg}$. of alcoholic precipitate had a very similar and remarkable effect to that of parotin, as shown in Fig. 3441). In order to see the relationship between this effect and that on Ca-effect, the precipitate from the $12.5 \%$ ammonium solution, possessing a strong P-effect and weak Ca-effect, was submitted for test,

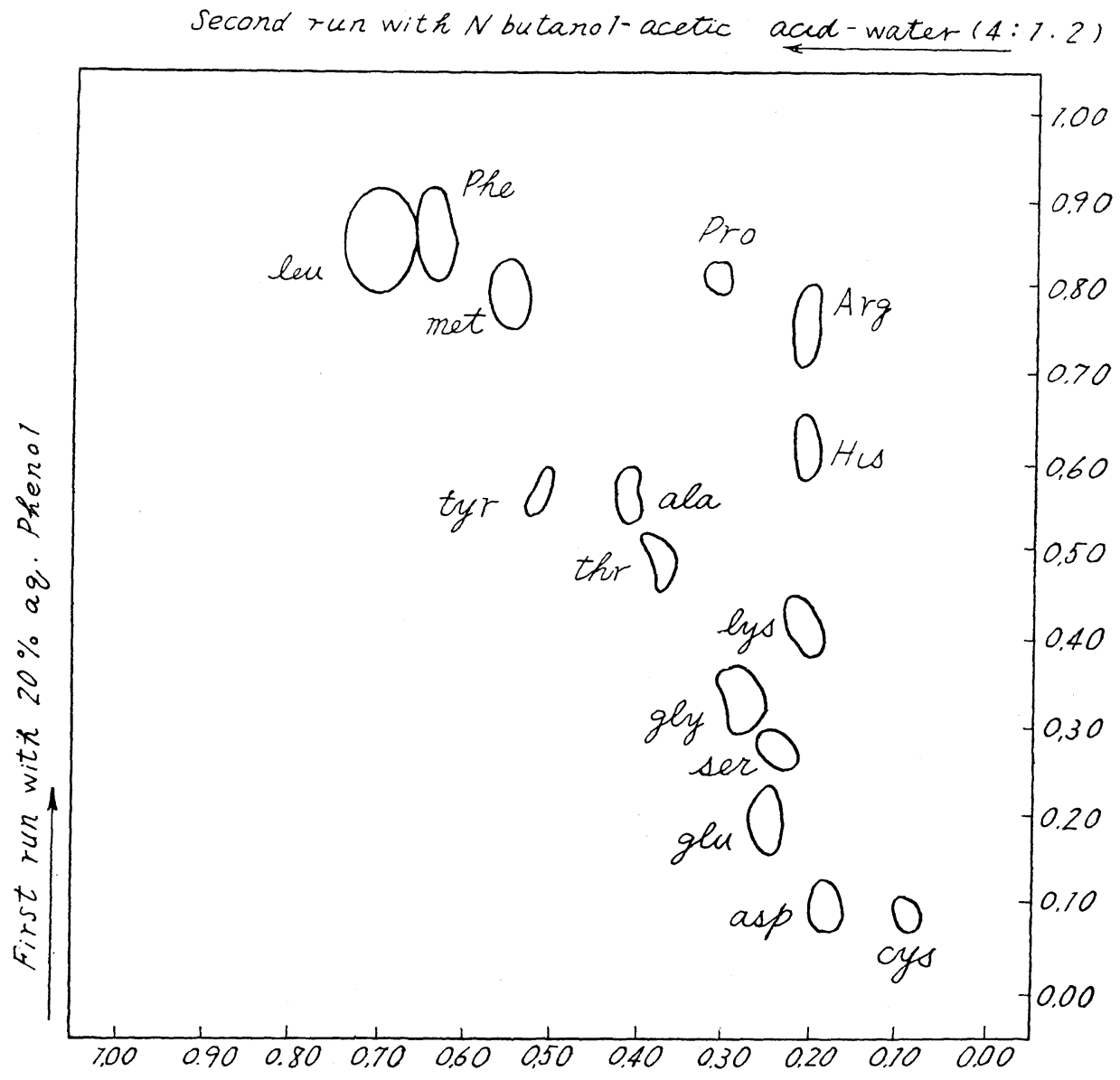

Fig. 32: Two-dimensional chromatogram of S-parotin hydrolvzate with $\mathrm{HCl}$. 
Second run with $N$ butanol-acetic acid-watar (4:1:2)

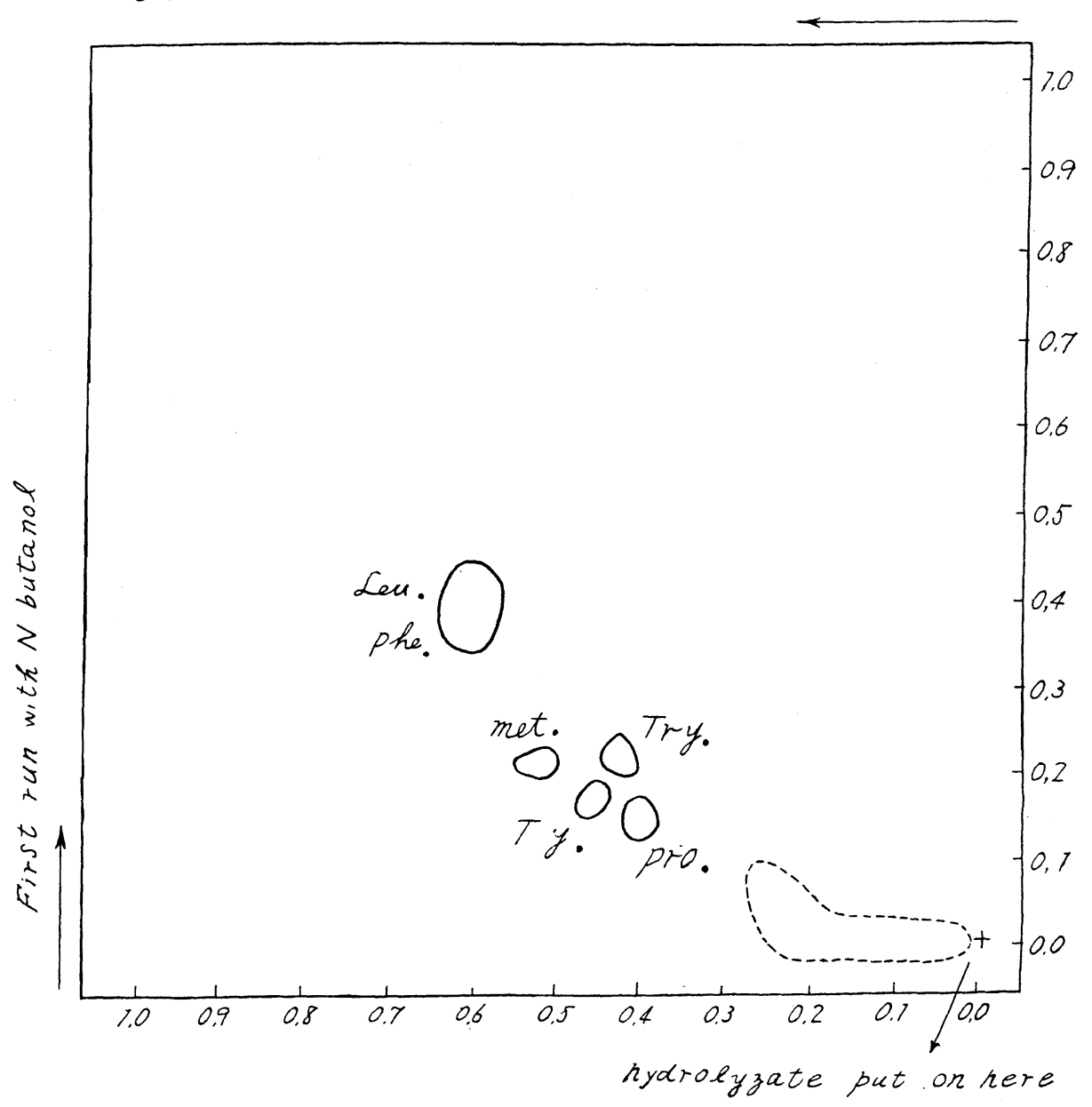

Fig. 33. Two-dimensional chromatogram of S-Parotin hydrolyzate with baryta.

as shown in Fig. 3541).

Administration of this precipitate did not cause as much leucocyte increase as that by the same amount of parotin. A larger effect was seen by doubling the doses. The human uro-parotin which has a smaller Cia-effect than parotin, posscssed comparatively small effect in increasing the number of leucocytes. It was also noticed that in human saliva the amylase portion which was found to have no Ca-effect, possessed no leucocyte effect either. However, parotin precipitate having a strong Ca-effect had also a strong leucocytes effect (Fig. 36). Considering these facts, it is highly possible that there must be a close relationship between the Ca-effect and effect of increasing the number of circulating leucocytes. 


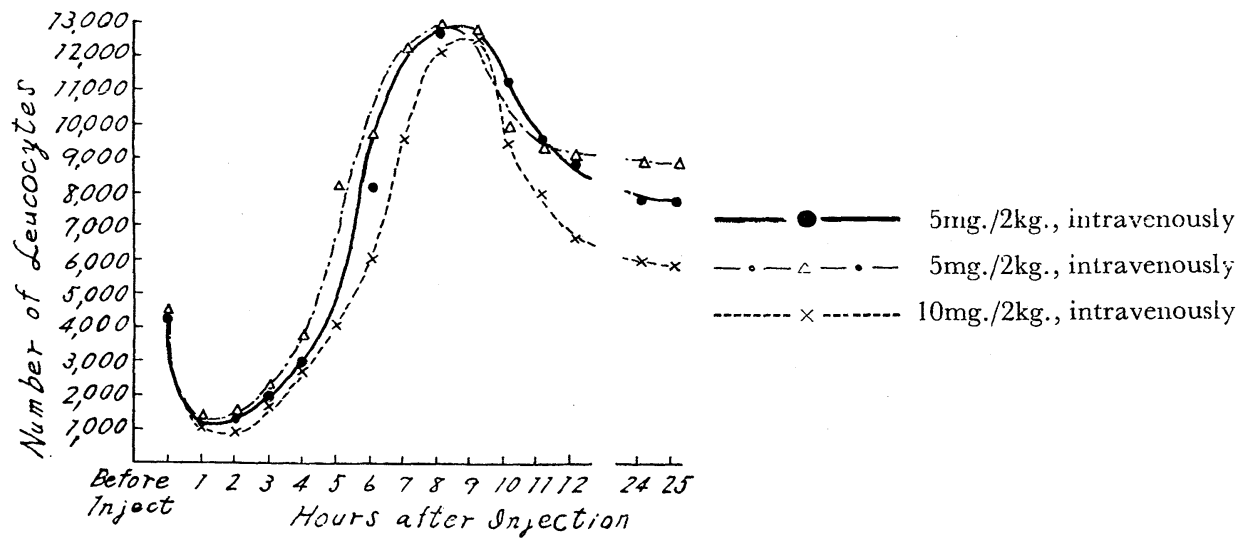

Fig. 34. The effects of $80 \%$ alcohol-precipitate from submaxillary gland extract on the number of circulating leucocytes in rabbits.

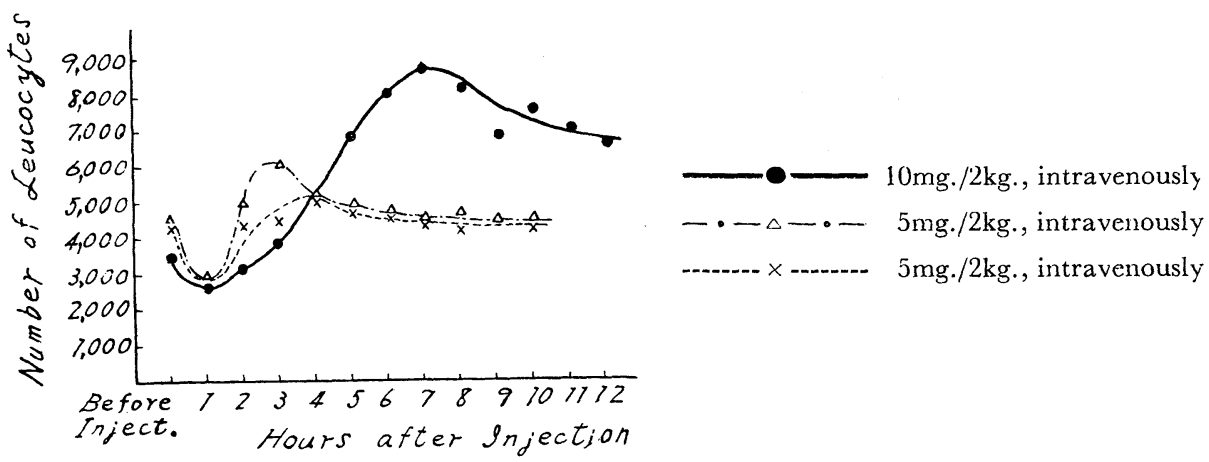

Fig. 35. The effect of $\left(\mathrm{NH}_{4}\right)_{2} \mathrm{SO}_{4}$ 12.5\%-precipitate from submaxillary gland extract on the number of circulating leucocytes in rabbits.

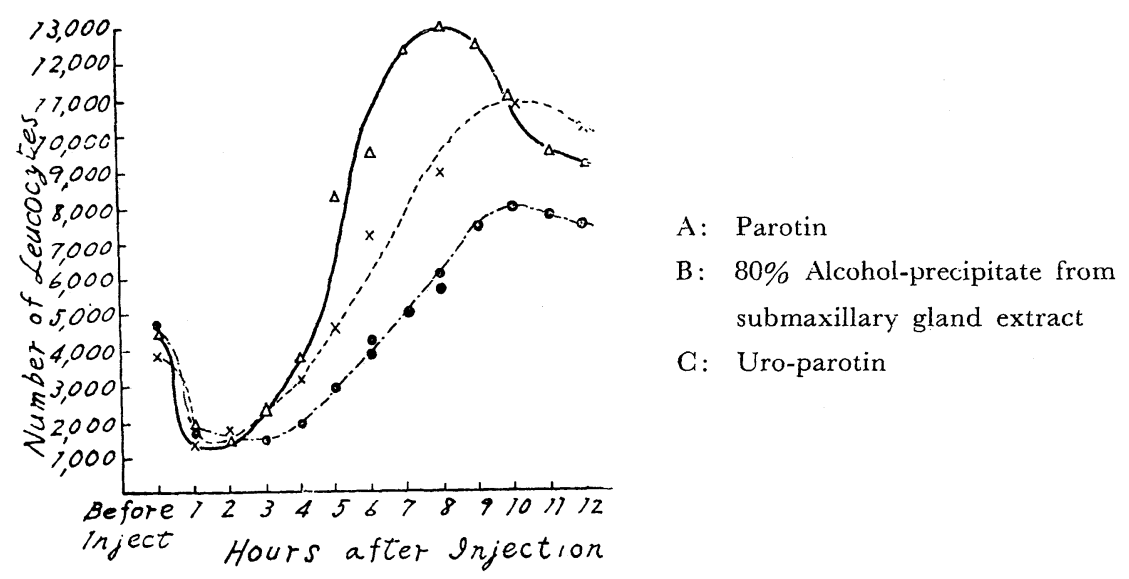

Fig. 36. The comparison of the effects of parotin, uro-parotin and S-parotin on the number of circulating leucocytes in rabbits. 
We obtained recently two isoelectric point precipitates, e.g., $\mathrm{pH} 5.4-$ and $\mathrm{pH}$ 4.5 precipitate, from horse submaxillary gland extract 44 ). Both precipitates were fractionated with ammonium sulfate in the same way as that of extract from bovine gland as above described, respectively, and we found that the $12.5 \%$ ammonium sulfate precipitate from the $\mathrm{pH}$ 5.4-precipitate contained principally Ca-substance and the P-effect was concentrated in the $25 \%$ ammonium sulfate precipitate from the $\mathrm{pH}$ 4.5-precipitate ${ }^{45)}$. The former fraction had the same effect on the number of the circulating leucocytes in rabbits as parotin and Sparotin and had $74.07 \%$ purity ${ }^{44)}$. It gave all positive coloring and precipitating reactions of protein and had maximum absorption spectrum at $276 \mathrm{~m} \mu .45)$.

The studies on the submaxillary extracts are now being continued. The results of the experiments mentioned above showed that the submaxillary gland contained not only a P-substance but also a Ca-substance. It was also shown by the experiments that $\mathrm{pH}$ 4.5-precipitate from the submaxillary gland promoted the calcification of rabbit incisor dentin as parotin did and that the precipitate with strong $\mathrm{Ca}$-effect had the same physical and chemical properties and the biological activity as those of parotin. These results could be considered to be one of the proofs of the idea that the submaxillary gland cooperates with parotin in the endocrine function of salivary glands.

\section{BIOLOGICAL ACTIONS OF PURIFIED PAROTIN}

The facts which have been found by the Parotin Research Group are described in this chapter.

The preparation used in these experiments was the precipitate (about 90\% purity) from the $20 \%$ ammonium sulfate solution, when required for special purposes, the precipitate trom $15 \%$ ammonium sulfate was used.

\section{I) AGTION ON HARD TISSUES}

The action of the crude parotin on hard tissues has already been described. The purified parotin also promotes the growth of hard tissue as the crude parotin. Dr. S. Huse (Gunma University) ${ }^{46)}$, using the precipitate from the $15 \%$ ammonium sulfate solution, proved by the "Okada-Mimura's time marking method by the lead acetate vital staining" that parotin promoted the calcification of rabbit incisor dentine. The minimum effective dose was $0.3 \mathrm{mg} . / \mathrm{kg}$. body weight of a single intravenous injection and $3 \mathrm{mg} . / \mathrm{kg}$. of a single subcutaneous injection. In the larger amount, such as $3.0 \mathrm{mg}$. $/ \mathrm{kg}$. (intravenous injection) and $5.0 \mathrm{mg} . / \mathrm{kg}$. (subcutaneous injection), caused not only inhibitive effect and deterioration of the dentine quality but also a decrease of growth rate. He also found that the effect by single subcutaneous injection lasted comparatively longer. Using the same lead acetate vital staining method, Dr. M. Okada (Tokyo Medico-Dental College $)^{47)}$ also found that $0.5 \mathrm{mg} . / \mathrm{kg}$. of the precipitate from $20 \%$ ammonium sulfate solution (daily single injection for three consecutive day) promoted the deposition of calcium in rabbit incisor dentine, but that a dose of $1 \mathrm{mg}$. $/ \mathrm{kg}$. of daily single subcutaneous injections in rat for four consecutive days caused the 
promotion during the administration, followed by a return to the normal state, and that $30 \mathrm{mg}$. $\mathrm{kg}$. of the same administration caused a notable inhibition during the four days of injection followed by a slight promotive effect. Dr. T. Sasaki (Chiba University) ${ }^{48}$ ) measured the amount of total ash, $\mathrm{Ca}, \mathrm{Mg}$, and $\mathrm{P}$, of diaphysis and metaphysis, incisor, and vertebral bone of litter rats divided into four groups, namely, parotin-injected intact group, salivary gland-ectomized group, parotin injected salivary gland-ectomized group, and the untreated control group. $\mathrm{He}$ reported that the content of these inorganic substances as maximum in the parotin injected group, and minimum in the salivary gland-ectomized group. These four groups were also fed with the same food, given subcutaneous injection of $\mathrm{P}^{32}$, and the distribution of $\mathrm{P}^{32}$ in the body was examined. The excretion rate of $\mathrm{P}^{32}$ into urine, as well as the concentration in blood in the salivary glandectomized group, were both large in the beginning, followed by rapid decrease. In the parotin-injected group these values were both small in the beginning, followed by rapid decrease. However, the amount of phosphorus excreted in urine was almost the same in all the groups and there was no difference by groups in the percentage of phosphorus absorbed through the intestinal canal. As for the distribution of $\mathrm{P}^{32}$ to bones in the parotin injected group a rather larger amount of $\mathrm{P}^{32}$ was found in the epiphysis of long bone and vertebrae, which largely consist of cartilage. A small amount of $\mathrm{P}^{32}$ was found in the same part of the salivary gland-ectomized group.

Radioautography of bones showed that promotive effect of parotin on the $\mathrm{P}^{32}$ distribution to epiphysis was seen from provisional calcified zone to the calcified zone. This finding was said to suggest that parotin affected the ossification.

In order to see the difference of growth-promoting effect of parotin on the bones by ages, Dr. Sasaki used three groups of rats, namely, infant group (50 days old), mature group (60-120 days) and aged group (150-180 days). Each group was divided into two groups, the parotin-injected group and the control group. The ratio of total ash, $\mathrm{Ca}, \mathrm{Mg}$, and $\mathrm{P}$ of bones to the amount in the control were examined. The increase of distribution of $\mathrm{P}^{32}$ to hard tissues was also examined. As a result, a much greater ratio of increase and more distribution were recognized in the younger group. This proved that parotin effect on bones varies by ages and that the younger the subject is the more effective is the parotin.

The author and his collaborators ${ }^{49)}$ examined statistically the effect of parotin on the distribution of $\mathrm{P}^{32}$ in intact rats, especially to the incisors. As a fundamental consideration the wet weight and ash of the femurs and these of incisors were measured. There was no correlation between these weights and distribution of $\mathrm{P}^{32}$ to bones. The error of the experiment was statistically analyzed to determine the errors due to individual differences, to differences between the left and right femurs of each animal, to the procedures of sample preparation from the same femur and to the repeated counting by the Geiger-Müller counter. As was expected, the error due to individual differences was found to be predominantly large, and it was discovered that the factor beyond the researcher's control had much larger effect on the experiment than did the experimental technique. Under the following four conditions, the radioactivities of femur, lower incisors, 
blood level and the adrenal were measured.

1) Concurrent administration of $2 \mathrm{mg} . / 100 \mathrm{~g}$.b.wt. of parotin (precipitate from $15 \%$ ammonium sulfate solution) and radioactive phosphate by subcutaneous injection, and the rats were sacrificed three hours afier treatment.

2) Subcutaneous injection of $3.1 \mathrm{mg}$. $/ 100 \mathrm{~g}$.b.wt. of parotin in three doses every two hours and radioactive $\mathrm{P}^{32}$ injected together with the last (third) injection of parotin. Sacrificed 24 hours after the injection of radioactive $P$.

3) Intraperitoneal injection of $0.8 \mathrm{mg} . / 100 \mathrm{~g} ., 0.2 \mathrm{mg} . / 100 \mathrm{~g}$., and $0.05 \mathrm{mg} . / 100 \mathrm{~g}$. of parotin, followed by the injection of radioactive phosphate three hours later, and sacrificed twenty-four hours after the last injection (tested by the two-way lay out with day of test and doses as the factors).

4) The same conditions as above with $0.05 \mathrm{mg}$. $/ 100 \mathrm{~g} . \mathrm{b} . \mathrm{wt}$. of parotin (tested by the two-way lay out with three repetitions).

As far as the counting is concerned, the G-M counting of soft tissue of the parotin-injected group was less than that of the control, and the counting of hard tissues of the parotin group was, with two exceptions, larger than that of the control. In view of statistical analysis of the data, however, only the difference of the counting of lower incisors' activity was significant between parotin injected animals and the control animals in some cases and not significant in other cases. The reason why all data did not show statistically significant differences from the control was considered to be due to the insufficient number of animals used and the conditions of experimentation; for instance, doses of parotin, the injection intervals between parotin and radio-active $\mathrm{P}^{32}$, the intervals between the time of the injections and the time when the animals were sacrificed.

Dr. M. Okada50) observed the effect of parotin on development and growth of hair, using the "Okada-Enaga's time marking method in hair by thallium acetate injection". He reported that there were no difference in the time of hair-development or in the type of development between the parotin treated animals and the control. However, the growth of hair was apparently promoted by $0.003 \mathrm{mg} . / \mathrm{g}$. of parotin injection, and inhibited by $0.03 \mathrm{mg}$. $/ \mathrm{g}$. of parotin injection during the injection period. Using the lead acetate stain method, he conducted a similar experiment on incisors and confirmed the report of Dr. Huse and Dr. Okada that deposition of calcium in the incisor dentin was promoted by a small dose of parotin and prohibited by a large dose.

Dr. T. Mori (Showa Medical College)51) observed the effect of parotin on the bone tissue of chick embryo and reported that parotin had a promotive effect on the growth in general and especially on the growth of the bone tissue. He surmised that promotion of ossification of the bone tissue is due to the fact that a certain amount of the calcium in the egg shell and of the egg itself moves very easily to the embryo by parotin injections. He also reported that injection of small amount of parotın cured imperfect growth of chick embryo caused by the loading of calcium preparations.

\section{II) EFFEGT ON INORGANIC SUBSTANCES IN BLOOD}

The author and his associates, as already mentioned, discovered that parotin decreased the serum calcium level in rabbit. This fact has later been confirmed 
by many workers. Dr. H. Minagawa (Tokyo University)52) reported that the same reaction could be seen in dog and human blood. He also found that parotin remarkably increased the magnesium level in the serum of rabbit, dog, and man.

The decrease of serum calcium level in blood, according to Dr. Y. Araki (Nagoya City University)53) occurs only in non-diffusible Ca-fraction and no change occurs in the diffusible Ca-fraction. He also reported a remarkable decrease in citric acid content in rabbit serum.

Although Dr. Minagawa reported no change of definite tendency in inorganic phosphorus content and alkaline phosphatase content in serum the author and his associates ${ }^{54)}$ found that intravenous injection of $2.5 \mathrm{mg} . / \mathrm{kg}$. of crude parotin and subcutaneous injection of $7.5 \mathrm{mg}$. $/ \mathrm{kg}$. of parotin caused an increase in the amount of inorganic phosphorus in serum, while purified parotin caused its decrease. The author ${ }^{55}$ ) noticed no difference in serum inorganic phosphorus in litter rabbits (30 day after birth) between those which were consecutively injected with parotin for one month and those without treatment. However, there was significant decrease $(\mathrm{P}=0.5)$ of alkali phosphatase in serum but not in adrenal cortex nor in proximal end of the tibia. No significant change of either serum calcium: or total serum protein was observed. Dr. K. Ota (Tokyo Medico-Dental College ${ }^{56)} \cdot$ reported that injection of parotin into adults, babies, and school children increased the amount of $\mathrm{Ca}$ in their saliva.

\section{III) RELATIONSHIP WITH OTHER ENDOGRINE ORGANS}

Dr. T. Ogata had long ago discovered that in case of asialadenism or hypersialadenism, there were definite changes in the tissues of other endocrine organs which suggest hyper- or hypo- function of these glands. Recently, Dr. T. Iino ${ }^{57)}$ and Dr. N. Takizawa58) (Chiba University) confirmed this fact. Dr. Takizawa58) proved that the tissues of the adrenal, the pituitary gland, the thyroid gland, and of the testicles of a parotin-administered rat showed the appearance, caused by an excess of the hormone, as that seen in the case of hypersialadenism. However, the effect of parotin on the tissues depended largely upon the doses, as did its effect on the calcification of rat incisor dentine. The above-mentioned effect of parotin on the tissues was seen only when a low dose $(0.3 \mathrm{mg} . / 100 \mathrm{~g}$.) was injected. When a high dose $(3.0 \mathrm{mg}$. $/ 100 \mathrm{~g}$.) was injected the appearance of the tissue was not necessarily the same as that of hypersialadenism, and three hours after injection the appearance was rather similar to that of hyposialadenism.

For instance, in the adrenal cortex of the animals injected with a large doses of parotin, a change was seen at the zona glomerulosa and the amount of lipoids decreased. The same tissues of the lower-dose group showed the appearance of cell multiplication and was rich in lipoids.

Dr. S. Tasaka59) reported that, in view of the Thorn's test and the number of eosinophiles in blood, parotin acted the same as ACTH.

He carried out the Thorn's test on both the salivary gland-ectornized animals and the animals injected with parotin after salivary gland ectomization. The result suggested slight hypofunction of the adrenal cortex in the former but not in the latter. 'Thus, he assumed that the endocrine function of the salivary gland 
has much to do with adrenal function. He also noticed a marked difference in the appearance of the tissues of both the pituitary anterior lobe and the adrenal between parotin-injected animal and ACTH-injected animals. In view of these findings, it is considered that parotin does not act directly on the adrenal but remarkably affected the eosinophile cell of the pituitary anterior lobe and then secondarily promoted the excretion of various hormones such as ACTH which all act on the adrenal.

Concerning this point, the author and other60) found that the injection of a small amount of parotin $(0.32 \mathrm{mg}$. $/ \mathrm{rat})$ caused a marked decrease in the amount of ascorbic acid in the adrenal of an intact rat but not of a hypophysectomized rat (ACTH-assay method by Sayers et al.61) ${ }^{62}$ ).

Although Dr. Tasaka reported that there was an increase of 17-ketosteroids in the urine of patients administered with parotin, the author and others ${ }^{63)}$ found no significant increase in the amount of 17-ketosteroids in urine of the rabbit administered with parotin. The experiment was as follows: Six rabbits were divided into three groups, of non-treatment group (control), low-dose parotin (2 mg./kg.) group and high-dose $(20 \mathrm{mg} . / \mathrm{kg}$.) group. The kind of treatment, the day of experiment and the kind of groups were used as a factor in the $3 \times 3$ Latin squares. The amount of 17-ketosteroids excreted in urine during 24, 48, and 72 hours after the administration were studied respectively in view of statistics and it was found that parotin did not affect either the volume of urine or the amount of 17-ketosteroids excreted in the urine and that the average amount of 17-ketosteroids in the urine of the control group was $0.723 \pm 0.425$ mg./day and had no correlation with the volume of urine. A correlation was observed, however, between the volume of urine in the low-dose group and the amount of 17-ketosteroids during 24 hours.

Furthermore, the author and his associate ${ }^{62}$ ) found that in the intact rats the decrease rate of ascorbic acid of the adrenal cortex decreased with an increased dose of parotin (for instance $2 \mathrm{mg}$. $/$ rat did not cause any change). To the contrary, the decrease rate of the ascorbic acid was increased with the increased dose of ACTH. This was later confirmed by Dr. Tasaka59). Thus, parotin shows different functions from that of AC'IH.

\section{IV) ACTION ON 'THERMAL S'TRESS}

Dr. Tasaka ${ }^{12) 59)}$ discovered that the rabbits pretreated with parotin lived much longer than the control group under high temperatures and that a normal human adult administered with parotin subjectively felt less pain and could withstand high temperatures better and sweated less than the control. He measured the volume of perspiration under high temperatures by the Takagi's method and reported two cases in which the amount of perspiration decreased from that of the control when given intramuscular injection of parotin 1 hour before the experiment.

\section{V) EFFECT ON PROTEIN METABOLISM}

The parotin action on the decrease of serum protein observed by the author ${ }^{10)}$ and Dr. Y, Takaoka"1) has already been stated in this paper ( $c f$. "Bioassay of 
Parotin"). Dr. Takaoka also discovered that in the salivary gland ectomized dog and rabbit the protein ratio (the ratio of serum albumine to serum globulin) was far less than that of the normal animal. This change of ratio was found by electrophoretic analysis to be due to the decrease of albumin and the increase of $\alpha$-globulin and of the globulin corresponding to the medium peak in the electrophoresis curve (probably $\gamma_{1}$-globulin). The intravenous injection of parotin ( $10 \mathrm{mg} . / \mathrm{kg}$.) into such a rabbit under asialadenism caused the increase of the protein ratio, which was found to be due to the increase of albumin and the decrease of $\alpha$ - or $\gamma$-globulin. He further reported that intraperitoneal injection of parotin $(2.5-5.0 \mathrm{mg}$. $/ 100$ g.) into rats remarkably decreased the total amount of nitrogen in urine excreted during one day and that administration of parotin to rabbits caused a decrease of the total amount of nitrogen and a stoppage of creatin excretion in urine, a decrease of residual nitrogen in serum and decrease of serum potassium and calcium. Dr. Tasaka59) also reported that administration of parotin $(5 \mathrm{mg} . / 2 \mathrm{~kg}$.) to male rabbits caused a decrease of total nitrogen in urine, a decrease of total creatine, and creatinine, and a tendency toward decrease of residual blood nitrogen. $\mathrm{He}$ also found that the consecutive administration of the same dose of parotin for five days, caused a decrease of total nitrogen in urine, total creatine, and of creatinine and a tendencey of decreasing residual nitrogen in blood.

\section{VI) ACTION OF ELEVATING BONE MARROW TEMPERATURE}

Dr. S. Tasaka ${ }^{12) 59)}$ studied the effect of parotin on regulation of body temperature and learned that intravenous injection of parotin $(1-3 \mathrm{mg} . / \mathrm{kg}$.) into an aural vein of rabbits caused a selective and a gradual raise of bone marrow temperature $\left(1.0-2.0^{\circ} \mathrm{C}\right)$ during about 90 minutes and lasted for some time. The injection of parotin (1/5-1/10 of a dose of intravenous injection) into the cisterna caused a similar marked rise of bone marrow temperature, as in the case of the intravenous injection, and this effect was accompanied by a temperature rise in the parotid gland and a rapid drop of thyroid gland temperature.

\section{VII) EFFECT ON HEMOGRAMM}

The effect of parotin of the number of circulating leucocytes has already been mentioned in this paper ( $c f$. "Bioassay of Parotin"). Dr. Takaoka11)64) administered spleen-ectomized rats with parotin and noticed the same increase of leucocytes and a decrease of acidophiles as in the case of intact animals. Thus he proved that neither the adrenal nor the spleen has to do with leucocytosis. Dr. S. Hara ${ }^{13)}$ reported that administration of parotin caused a general increase of not only leucocytes but also lymphocytes, pseudoacidophiles, acidophiles, and reticulocytes. No effect was seen on the number of blood platelets, and erythrocytes, the amount of hemoglobin, or the hematocrit value.

\section{VIII) EFFECT ON LIPOIDS CONTEN'T OF THE SKIN}

Dr. K. Kitamura (Tokyo University) ${ }^{65)}$ ascertained that 2, 4 hours after either a single or a continuous injection of parotin, the amount of lipoids increased in the epidermis of central portion of the inner side of forearm. 


\section{IX) INVERSION OF THE EFFECT BY A LARGE DOSE}

As has already been stated, a small dose of parotin caused the promotion of calcification in rat and rabbit incisors, acceleration of hair growth in rat, decrease of adrenal ascorbic acid, and hypertrophy of the adrenal cortex. A large dose of about ten times this dose was found to reverse these effects.

\section{X) TOXICITY}

Dr. Hara66) reported that either subcutaneous or intravenous injection of various amounts of a $1 \sim 2 \%$ solution of parotin did not cause any visible toxic effect on frogs, mice, and rabbits. The author67) also found that a consecutive administration of parotin for 10 days (a daily single subcutaneous injection of $1.0 \mathrm{mg} .(0.5 \mathrm{cc})$.$) to either male or female rats of 118 \sim 158 \mathrm{~g}$. body weight, did not cause any visible toxic effect at all, or a single subcutaneous injection of $50 \mathrm{mg}$. $(5 \mathrm{cc}$.) into male rat did not cause any apparent toxic effects either.

\section{CONGLUSION}

The results of the salivary gland hormone study and the outline of the biological activity of parotin, which was found by the research group, were reported. The author and his associates reached the stage of isolating a new protein from the bovine parotid gland and found that this substance had not only many biological activity but also exclusive action exactly like that of the salivary gland hormone, which has been proposed by the salivary gland endocrine theory. $\mathrm{He}$ also found various biological activity of this substance. Whether this substance is the salivary gland hormone itself or not is the problem which can only be answered later by future studies from various angles. As for the physical, chemical, and biochemical study of the parotin protein mentioned in this paper, much is left to be studied later. Criticism and investigations by those who have interest in it would be very much appreciated by the author.

The studies made at the author's laboratory was started under the guidance of Dr. Akira Ogata, professor emeritus at Tokyo University and succeeded by the author as he retired. 'The author is greatly appreciative of the cooperation of Dr. Yasuhiko Nozaki, Mr. Sahichi Okabe, Mr. Akira Mizutani, Mr. Shigeru Aonuma, Mr. Susumu T'surufuji, Mr. Yukio Kubota, Miss Masako Egusa, Mr. Masato Shinoda and Mr. Mitsuo Sawada. Studies of this hormone are also being made at the Department of Physiological Chemistry in the Endocrinological Laboratories at Gunma University, with cooperation of Assistant Professor Mr. Hiroo Takigawa, and Assistant Mr. Sakuji Miyashita and Miss Keiko Ono. The author is further indebted to the Teikoku Hormone Manufacturing Co. Ltd. for supplying material used in the experiment and to Nippon Gakujutsu Shinkokai (Japan Science Furtherance Association) and the Ministry of Education for financial assistance. The expenditure of this study were defrayed by the former before the end of the war and by the latter after that. 


\section{REFERENGES}

ia) Ogata, T.: Tetsumon 5: 2, 1943; Igakusoho 1:301, 1946. (In Japanese)

1b) Ogata, A., Y. Ito, Y. Nozaki, S. Okabe, T. Ogata and Z. Ishii: Medicine and Biology 5: 253, 1944. (In Japanese)

2) Ito, Y. and A. Mizutani: "Studies on the Salivary Gland Hormones" (Hereafter this title is abbreviated as "Studies") XIV, J. Pharmaceut. Soc. Japan 72: 244, 1952.

3) Report from the Seventh Consolidated Research Group organized on the Scientific Research Fund of the Ministry of Education (Hereafter this report will be described as Education Ministry Report): 193, 1951; 101, 1952. (In Japanese)

4) Ishii, Z. : J. Pathology Japan 3 : 103, 1945. (In Japanese)

5) Ogata, A., Y. Ito, Y. Nozaki and S. Okabe: "Studies" II, J. Pharmaceut. Soc. Japan 64: 114, 1944. (In Japanese)

6) Ogata, A. and Y. Ito: "Studies" V, J. Pharmaceut. Soc. Japan 64: 332, 1944. and see also 5); Ito, Y. and A. Mizutani: "Studies" XVII, J. Pharmaceut. Soc. Japan, 72: 1468, 1952. (In Japanese)

7) Ogata, A. and Y. Ito: "Studies" III, J. Pharmaceut. Soc. Japan 64: 146, 1944. (In Japanese)

8) Ogata, A. and Y. Ito: "Studies" V, J. Pharmaceut. Soc. Japan 64: 332, 1944. (In Japanese)

9) Ito, Y., B. Kobayashi and M. Kurihara: "Studies", XXVIII, The Japanese Journal of Endocrinology 29: 18, 1953. (delivered at the 26th Annual Meeting of the Endocrinological Society of Japan 1953). (In Japanese)

10) Ito, Y. and S. Tsurufuji: "Studies" XXIII, J. Pharmaceutic. Soc. Japan 73: 151, 1953. (delivered at the Annual Meeting of the Pharmaceutical Soc. of Japan 1950). (In Japanese)

11) Takaoka, Y., T. Yamaguchi and K. Kosaka: The Tohoku Journal of Exper. Med. 57: 9, 1952.

12) Tasaka, S., O. Takatani and K. Narita: The Tokyo Journ. of Med. Science 59: 227, 1952. (In Japanese)

13) Hara, S.: Education Ministry Report, 108, 1952. (In Japanese)

14) Ogata, A., Y. Ito and A. Mizutani: "Studies" IV, J. Pharmaceut. Soc. Japan 64: 325, 1944 and also 1) and 5). (In Japanese)

15) Huse, S.: Education Ministry Report, 199, 1952; Sato, 'T.: Gunma Journal of Med. Sci. 2 : 183, 1953.

16) Ogata, A., Y. Ito, A. Mizutani and Y. Sakaguchi: "Studies" VII, J. Pharmaceut. Soc., Japan 65 : 9, 1945. (In Japanese)

17) Ogata, A., Y. Ito, A. Mizutan! and Y. Sakaguchi: "Studies" VIII, J. Pharmaceut. Soc. Japan 65: 20, 1945. (In Japanese)

18) Ito, Y. and A. Mizutani: "Studies" XIII, J. Pharmaceut. Soc. Japan 72: 239, 1952.

19) Ito, Y., H. Takigawa and S. Ota: "Studies" XXVI, Japanese Endocrinology 29 : 18, 1953; J. Pharmaceut. Soc. Japan 74: 1954. (In press)

20) Ito, Y., Y. Kubota, H. Endo and M. Kikuchi: J. Pharmaceut. Soc. Japan 74 : 1954. (In press)

21) Ito, Y. and A. Mizutani: "Studies" XVIII, J. Pharmaceut. Soc. Japan 72: 1499, 1952. (In Japanese)

22) Mizutani, A. : "Studies" XXI, J. Pharmaceut. Soc. Japan 72: 1511, 1952. (In Japanese)

23) Gurin, S. and D.B. Hood: J. Biol. Chem. 131: 211, 1939.

24) Devor, A.W.: J. Amer, Chem. Soc. 72: 2008, 1950. 
25) Mizutani, A. : "Studies" XXII, J. Pharmaceut. Soc. 72: 1514, 1952. (In Japanese)

26) Hinsberg, K. and L.L. Lang: Medizinische Chemie 191, 1938.

27) Mizutani, A. : "Studies" XIX, J. Pharmaceut. Soc. Japan 72: 1503, 1952. (In Japanese)

28) Mizutani, A. : "Studies" XX, J. Pharmaceut. Soc. Japan 72 : 1507, 1952. (In Japanese)

29) Ito, Y. and A. Mizutani: "Studies" XV, J. Pharmaceut. Soc. Japan 72: 1462, 1952. (In Japanese)

30) Granados, H. : Acta Physiologica Scandinavica 24: Suppl. 87, 1951.

31) Ogata, A., Y. Ito and S. Okabe: "Studies" I, J. Pharmaccut. Soc. Japan 64: 79, 1944. (In Japanese)

32) Ogata, A., Y. Ito and A. Mizutani: "Studies" VI, J. Pharmaceut. Soc. Japan 64: 337, 1944. (In Japanese)

33) Ito, Y. and S. Okabe: "Studies" XXIX, J. Pharmaceut. Soc. Japan 74: 1954 (In press), (delivered at the 26th Annual Meeting of Biochemical Society of Japan, 1954).

34) Ito, Y. and S. Okabe: Unpublished.

35) Mayer et al.: Helvetica Chimica Acta 31: 2158, 1948.

36) Ito, Y., S. Aonuma and M. Sawada: "Studies" XXIV, J. Pharmaceut. Soc. Japan 74: 142, 1954. (In Japanese)

37) Ito, Y. and S. Aonuma: "Studies on the Submaxillary Gland" I, J. Pharmaceut. Soc. Japan 72: 1517, 1952. (In Japanese)

38) Ito, Y., S. Aonuma and M. Shinoda: "Studies on the Submaxillary Gland" II, J. Pharmaceut. Soc. Japan 73: 1361, 1953. (In Japanese)

39) Matsuda, N.: J. Med. Soc. in Northern Kanto 2: 227, 1953. (In Japanese)

40) Ito, Y., S. Aonuma and M. Shinoda: "Studies on the Submaxillary Gland" III, J. Pharmaceut. Soc. Japan 73: 1366, 1953. (In Japanese)

41) Ito, Y., S. Aonuma and M. Shinoda: "Studies on the Submaxillary Gland" IV, J. Pharmaceut. Soc. Japan 73: 1370, 1953. (In Japanese)

42) Ito, Y., S. Aonuma, H. Takigawa and M. Shinoda: "Studies on the Submaxillary Gland" V, J. Pharmaceut. Soc. Japan 74: 1954. (In press)

43) Ito, Y., S. Aonuma and H. Honda: "Studies on the Submaxillary Gland" VII, J. Pharmaceut. Soc. Japan 74: 1954. (In press)

44) Aonuma, S. and T. Hama: "Studies on the Submaxillary Gland" VIII, J. Pharmaceut. Soc. Japan 74: 1954. (In press)

45) Aonuma, S. and T. Hama: "Studies on the Submaxillary Gland" IX, J. Pharmaceut. Soc. Japan 74: 1954. (In press)

46) Huse, S. and T. Sato: Education Ministry Report 109, 1952. (In Japanese)

47) Okada, M., T. Enaga and A. Ryo: Report at the Parotin Research Congress, Feb. 7, 1953.

48) Sasaki, 'T.: Acta Paediatrica 57: 7, 584, 1953.

49) Ito, Y., S. Tsuruhuji and Y. Kubota: "Studies" XXV, J. Pharmaceut. Soc. Japan 74 : 350, 1954. (In Japanese)

50) Okada, M., T. Enaga and S. Sekiya: Education Ministry Report 110, 1951. (In Japanese)

51) Mori, T.: J. of Med. Sci. of Showa Medical College (Showa Igakukai Zassi) 13 : 15, 24, 1953. (In Japanese)

52) Minagawa, H., O. Hukushima, H. Gunma and M. Oya: Sogo Igaku 9: 335, 1952. (In Japanese)

53) Araki, Y.: Education Ministry Report 107, 1952; "Nippon Rinsho" 11: 49, 1953. (In Japanese)

54) Ito, Y., A. Aonuma and K. Higashi: "Studies" XVI, J. Pharmaceut. Soc. Japan 72 1465, 1952. (In Japanese) 
55) Ito, Y. and S. Tsuruhuji: Report at the Parotin Research Congress, Febr. 7, 1953.

56) Oota, K.: Report at the Parotin Research Congress, Febr. 7, 1953.

57) Iino, K.: J. Pathology Japan 1951. (In Japanese)

58) Takizawa, N.: Report at the Annual Meeting of Japan Pathological Soc. 1953 ; Education Ministry Report 110, 1952. (In Japanese)

59) Tasaka, S. : Education Ministry Report 112, 1952; J. Pathology Japan 41: 212, 261, 1952. (In Japanese)

60) Ito, Y. and E. Takabatake: J. Pharmaceut. Soc. Japan 72 : 1063, 1952. (In Japanese)

61) Sayers, M. A., G. Sayers and L. A. Woodbury: Endocrinology 42: 379, 1948.

62) Ito, Y. and E. Takabatake: Education Ministry Report 113, 1952. (In Japanese)

63) Ito, Y. and M. Egusa: Unpublished.

64) Takaoka, Y.: Sogo Rinsho 2: 661, 1953; Education Ministry Report 114, 1952. (In Japanese)

65) Kitamura, K. : Education Ministry Report 120, 1952. (In Japanese)

66) Hara, S. : Report at the Parotin Sesearch Group Congress, July, 1951.

67) Ito, Y.: Report at the Parotin Research Group Congress, Febr., 1953. 